\title{
KAJIAN KESESUAIAN STANDAR CEMARAN KIMIA (LOGAM BERAT DAN PAH) PADA PRODUK PERIKANAN DI INDONESIA DENGAN STANDAR NEGARA LAIN DAN CODEX
}

\section{Compliance Assessment of Chemical Contaminant Standard (Heavy Metal and PAH) for Fishery Products in Indonesia with those of Other Countries and Codex}

\author{
Oryssa Sathalica Pradianti ${ }^{1,2^{*}}$, Winiati Pudji Rahayu ${ }^{3,4}$, dan Ratih Dewanti-Hariyadi ${ }^{3,4}$ \\ ${ }_{1}^{1}$ Program Studi Magister Profesional Teknologi Pangan, Institut Pertanian Bogor, Bogor, Indonesia \\ ${ }_{2}^{2}$ Pusat Pengendalian Mutu-Kementerian Kelautan dan Perikanan, Jakarta, Indonesia \\ ${ }^{3}$ Departemen IImu dan Teknologi Pangan, Institut Pertanian Bogor, Bogor, Indonesia \\ ${ }^{4}$ Seafast Center, Institut Pertanian Bogor, Bogor, Indonesia \\ *Korespondensi Penulis: oryssasp@gmail.com
}

Diterima: 1 Oktober 2018; Direvisi: 19 Februari 2019; Disetujui: 28 Mei 2019

\begin{abstract}
ABSTRAK
Pangan dapat terkontaminasi oleh cemaran kimia karena penanganan dan pengolahan pangan yang tidak sesuai. Tujuan dari penelitian ini adalah 1) mengidentifikasi mayoritas penyebab penolakan produk perikanan Indonesia, 2) menelaah standar cemaran kimia pada produk perikanan, khususnya logam berat yang ada di Indonesia, Codex Alimentariurs Commision (CAC) dan negara-negara lain, serta 3) memberikan rekomendasi bagi pemerintah selaku regulator dalam proses perumusan suatu standar. Dokumen standar cemaran kimia pada produk perikanan dikumpulkan dari dokumen/ peraturan yang dikeluarkan oleh Badan Pengawasan Obat dan Makanan (BPOM), Badan Standardisasi Nasional (BSN), CAC, dan 11 negara lain yaitu Uni Eropa, Kanada, China, Korea Selatan, Vietnam, Amerika Serikat, Jepang, Malaysia, Singapura, Thailand, dan Australia. Hasil penelitian menunjukkan bahwa dari 164 notifikasi penolakan produk perikanan Indonesia di Uni Eropa, Kanada, dan Korea Selatan selama 10 tahun (2008-2017), penolakan produk perikanan tertinggi disebabkan oleh adanya cemaran kimia merkuri dan metilmerkuri pada ikan todak sebesar $27 \%$, kadmium pada gurita sebesar $5 \%$ dan benzo[a]piren pada ikan asap sebesar 3\%. Batas maksimum cemaran kimia untuk arsen, kadmium, dan timbal (pada ikan predator) di Indonesia yang terdapat pada Peraturan Kepala (Perka) BPOM Nomor 5 Tahun 2018 lebih rendah dibandingkan dengan yang terdapat di SNI 7387:2009 maupun yang ditetapkan oleh CAC serta negara lain. Indonesia telah menetapkan batas maksimum benzo[a]piren pada ikan asap, sementara itu CAC hanya menetapkan code of practice terhadap benzo[a]piren. Peraturan cemaran logam berat belum sepenuhnya dipedomani oleh para eksportir sehingga masih terdapat penolakan produk perikanan Indonesia. Hal ini menunjukkan masih perlu dilakukan pengawasan terkait kandungan logam berat yang terdapat pada produk perikanan di Indonesia. Code of practice terkait proses pengolahan pangan direkomendasikan untuk diterbitkan guna meminimalisir kandungan benzo[a]piren.
\end{abstract}

KATA KUNCI : cemaran kimia, perikanan, logam berat, polycyclic aromatic cydrocarbon (PAH), Codex

\begin{abstract}
Food can be contaminated by chemical contamination through inappropriate food handling and processing. The purpose of this study aims to: 1) identify the chemical contamination caused majority of the rejection of Indonesia fishery products, 2) reviewing the chemical standards of contamination fishery products in Indonesia, Codex Alimentariurs Commision (CAC) and other countries, and 3) provide recommendations for the setting of chemical contamination standards in fishery products. Chemical contamination standards were collected from regulations issued by the Indonesia National Agency of Drug and Food Control (NADFC), National Standardization Agency of Indonesia, CAC, and 11 other countries: European Union/EU, Canada, China, South Korea, Vietnam, United States of America, Japan, Malaysia, Singapore, Thailand, and Australia. The results showed that in the 10 years period (2008-2017), there were 164 rejection notifications in EU, Canada, and South Korea and the highest rejection was caused by chemical contamination i.e. $27 \%$ caused by mercury and methylmercury in swordfish, 5\% caused by cadmium in octopus and 3\% caused by benzo[a]pyrene in smoked fish. The maximum limit of chemical contamination for arsenic, cadmium, and lead (predatory fish) in Indonesia as stated in the Regulation of the Head of NADFC Number 5 of 2018 lower than the maximum limit set in SNI 7387: 2009 and sets in CAC and other countries. Indonesia set the maximum
\end{abstract}


limit for benzo[a]pyrene in smoked fish, whereas CAC published the code of practice to avoid a benzo[a]pyrene formation. Regulations of maximum limit for heavy metal contamination have not been fully guided by fisheries exporters, so that there was still rejection of Indonesian fishery products. The action needed is tightening the monitoring of heavy metal in fishery products in Indonesia. Code of practice to avoid benzo[a]pyrene formation is recommended to set up to minimize the benzo[a]pyrene formation on food processing.

\section{KEYWORDS: chemical contaminants, fishery, heavy metal, polycyclic aromatic cydrocarbon (PAH), Codex}

\section{PENDAHULUAN}

Hasil perikanan adalah salah satu sektor strategis dalam pembangunan perekonomian nasional. Proses penanganan produk perikanan harus memenuhi persyaratan standar guna menghasilkan produk perikanan yang prima dan bermutu serta dapat bersaing di pasar Internasional. Indonesia termasuk salah satu pengekspor produk perikanan dunia, dalam bentuk segar, beku, maupun olahan dengan produk antara lain ikan, krustasea, moluska, dan produk perikanan lainnya. Volume produksi perikanan Indonesia tahun 2017 sebesar 23 juta ton, dengan rincian produksi perikanan tangkap dan perikanan budidaya berturut-turut sebesar 6,89 juta ton dan 16,1 juta ton (Kementerian Kelautan dan Perikanan, 2018). Berdasarkan data rekapitulasi sertifikat kesehatan ekspor hasil perikanan tahun 2016, volume ekspor produk perikanan Indonesia sebesar 737.906 ton dengan nilai 4 milyar US\$.

United Nations Industrial Development Organization (UNIDO) melakukan analisis terhadap data penolakan ekspor Indonesia oleh Amerika Serikat dan Uni Eropa selama periode tahun 2006-2010 yang tercantum pada Trade Standard Compliance Footprint2012: Import Rejection Analysis (Indonesia). UNIDO menyebutkan bahwa selama periode tahun 20062010, produk perikanan Indonesia mendapat notifikasi dari Uni Eropa sebanyak 82 notifikasi yang disebabkan oleh logam berat, residu obat hewan (antibiotik), bahan tambahan makanan yang dilarang, dan kontaminan lainnya. Di Amerika Serikat, produk perikanan Indonesia mendapat notifikasi penolakan sebanyak 1286 notifikasi yang disebabkan oleh lemahnya pengendalian terhadap higienitas produk.

Berdasarkan Rapid Alert System for Food and Feed Annual Report 2017 (European Union, 2018), merkuri pada ikan dan produk perikanan menempati posisi ke-2 penyebab penolakan atau notifikasi di Uni Eropa setelah Salmonella pada unggas. Merkuri pada ikan todak menunjukkan kasus terbanyak pada tahun 2017 dengan jumlah notifikasi sebanyak 61, dan 47 kasus dinotifikasi oleh Italia terhadap ikan todak yang berasal dari Spanyol.
Kontaminasi cemaran kimia pada produk pangan dapat menimbulkan dampak negatif terhadap kesehatan manusia. Pangan dapat terkontaminasi oleh cemaran kimia melalui beberapa faktor dan pengolahan pangan yang tidak sesuai. Konsumsi produk perikanan yang tercemar merupakan sumber utama terpaparnya manusia oleh merkuri. Ikan predator dapat terpapar merkuri dengan konsentrasi tinggi melalui proses bioakumulasi apabila dibandingkan dengan ikan non-predator (Anual et al., 2018). Food and Argiculture Organization (FAO)/World Health Organization (WHO)/Codex Alimentariurs Commision (CAC) dan otoritas keamanan pangan menetapkan standar merkuri pada ikan yang didasarkan pada toksisitas metil merkuri (Health Canada, 2008). Standar merkuri untuk ikan predator sebesar 1,0 ppm dan 0,5 ppm untuk ikan non-predator. Penggolongan ikan predator berbeda-beda pada setiap negara. Berdasarkan hasil penelitian Sadhu Jonathan, Hamish, dan Ben (2015), konsentrasi metilmerkuri pada ikan pink cusk eel (Genypterus blacodes) dari perairan Selandia Baru berkisar antara $0,023-2,515 \mu \mathrm{g} / \mathrm{g}$, dan ikan tersebut tergolong dalam jenis ikan predator.

Bioakumulasi logam berat tersebut terjadi melalui rantai pangan, yang berakhir pada konsumsi yang dapat berbahaya bagi kesehatan manusia. Sebagai konsekuensi dari hal tersebut, ikan sering digunakan sebagai indikator adanya kontaminasi logam berat pada ekosistem akuatik (Zaza, de Balogh, Palmery, Pastorelli, \& Stacchini, 2015). Kadmium, terutama yang berasal dari emisi pembakaran bahan bakar, merupakan sumber utama kadmium terlarut di laut dan bioakumulasi pada ikan. Toksisitas kadmium dapat menyebabkan gagal ginjal, hipertensi, gangguan neurologis dan pencernaan, serta kanker (Nunez, Garcia, Julian, \& Melgar, 2018). Penetapan batas maksimum cemaran kimia harus memperhatikan kriteria spesifik yaitu: informasi toksikologi, data analitik terkait jumlah dan prosedur sampling, data asupan produk pangan, pertimbangan teknologi proses, dan hasil kajian risiko dan manajemen risiko. Codex Alimentarius Commision (Codex) menetapkan 
General Standard for Contaminants and Toxins in Food and Feed (CODEX STAN 193-1995) tahun 1995.

Dalam rangka perlindungan terhadap masyarakat, suatu negara dapat menetapkan standar batas maksimum suatu cemaran pada produk pangan. Indonesia menetapkan batas maksimum cemaran kimia pada produk pangan pada dua peraturan, yaitu peraturan Kepala Badan Pengawas Obat dan Makanan (BPOM) serta tertuang dalam Standar Nasional Indonesia (SNI). Kepala BPOM juga menetapkan peraturan terbaru untuk beberapa jenis cemaran kimia yang ditetapkan dalan Peraturan Kepala BPOM Nomor 5 Tahun 2018 tentang Batas Maksimum Cemaran Kimia dalam Pangan Olahan.

Adanya kasus penolakan ekspor yang disebabkan adanya cemaran kimia, diduga disebabkan karena adanya ketidakharmonisan terkait penentuan kriteria cemaran kimia, mulai dari penetapan batas maksimum, metode pengujian, serta prosedur dan jumlah pengambilan sampel untuk monitoring. Hal tersebut juga dapat disebabkan karena tidak dilakukannya monitoring cemaran kimia pada produk perikanan dengan baik. Berdasarkan hal tersebut, maka perlu dilakukan penelaahan terhadap standar cemaran kimia yang ada di Indonesia, CAC dan negara-negara lain sehingga dapat memberikan rekomendasi bagi pemerintah selaku regulator dalam proses perumusan suatu standar dan dapat diimplementasikan guna menjamin produk pangan yang bebas dari cemaran kimia.

\section{BAHAN DAN METODE}

\section{Bahan}

Bahan yang digunakan pada penelitian ini terdiri dari beberapa dokumen atau peraturan yang diterbitkan oleh BPOM, Badan Standardisasi Nasional (BSN), CAC, dan beberapa standar cemaran kimia negara lain yaitu Uni Eropa, Kanada, China, Korea Selatan, Vietnam, Amerika Serikat, Jepang, Malaysia, Singapura, Thailand, dan Australia. Data penolakan diperoleh dengan mengakses website rapid alerts system for food and feed (RASFF) Portal Uni Eropa serta data penolakan ekspor dari negara tujuan ekspor lainnya.

\section{Metode}

Metode pada penelitian ini adalah metode analisis deskriptif, yang merupakan metode yang digunakan untuk mencari unsur-unsur, ciri-ciri, sifat-sifat suatu fenomena. Penelitian ini dimulai dengan mengumpulkan, menganalisis dan menginterpretasikan data (Suryana 2010). Tahapan secara rinci adalah: 1) analisis penolakan produk perikanan yang disebabkan oleh cemaran kimia, 2) identifikasi standar cemaran kimia pada produk perikanan di Indonesia, CAC dan negara lain, 3) kaji banding standar cemaran kimia di Indonesia, CAC dan negara-negara lain terhadap produk perikanan dengan notifikasi penolakan ekspor tertinggi, 4) penyusunan rekomendasi penerapan standar cemaran kimia pada produk perikanan di Indonesia.

\section{Analisis penolakan produk perikanan yang disebabkan oleh cemaran kimia}

Analisis penolakan produk perikanan dilakukan berdasarkan jumlah kasus penolakan ekspor produk perikanan Indonesia yang disebabkan oleh cemaran kimia pada periode tahun 2008-2017. Data jumlah kasus penolakan dihitung berdasarkan jumlah notifikasi yang terdapat pada website RASFF portal negara Uni Eropa (https://webgate.ec.europa.eu/rasffwindow/portal/?event=SearchForm \&cleanSearch=1) serta notifikasi penolakan ekspor dari negara lainnya, yaitu dari Kanada, Korea Selatan, China, dan Vietnam. Penentuan kelima negara tersebut dikarenakan adanya pengakuan kesetaraan sistem jaminan mutu dan keamanan hasil perikanan sehingga Indonesia mendapatkan notifikasi apabila terdapat penolakan ekspor produk perikanan. Pada tahapan ini ditetapkan tiga jenis cemaran kimia yang paling banyak mengontaminasi produk perikanan antara lain: merkuri, kadmium, dan benzo[a]piren. Persentase penolakan pada masing-masing negara yang disebabkan oleh cemaran tertentu dihitung berdasarkan jumlah cemaran tertentu dibagi jumlah penolakan di negara tersebut.

\section{Identifikasi standar cemaran kimia pada produk perikanan di Indonesia, CAC dan negara-negara lain}

Pengumpulan standar cemaran kimia untuk produk perikanan dilakukan dengan mengakses situs web resmi otoritas standar mutu dan keamanan pangan di Indonesia (BSN dan BPOM). Selain itu dilakukan juga akses pada laman resmi otoritas yang menerbitkan standar di 11 negara dan mengunduh dokumen standar mutu dan keamanan pangannya. Negara-negara tersebut adalah Uni Eropa, Kanada, China, Korea Selatan, Vietnam, Amerika Serikat, Jepang, Malaysia, Singapura, Thailand, dan Australia. Pemilihan 11 negara tersebut didasarkan pada jumlah ekspor produk perikanan pada tahun 2016 dan 2017. Selain hal tersebut, dari 11 negara yang dipilih terdapat 5 (lima) negara antara lain: Uni Eropa, Kanada, China, Korea Selatan, dan Vietnam dari 7 (tujuh) negara yang telah memiliki kerjasama dalam bidang sistem jaminan mutu dan kemananan hasil perikanan. Standar cemaran juga diambil dari CAC sebagai 
Tabel 1. Alamat situs web standar cemaran kimia di berbagai negara

Table 1. Website of contaminants standard in many countries

\begin{tabular}{cll}
\hline $\begin{array}{c}\text { No/ } \\
\text { No }\end{array}$ & \multicolumn{1}{c}{\begin{tabular}{c}
\multicolumn{1}{c}{ Negara/ } \\
Country
\end{tabular}} & \multicolumn{1}{c}{ Situs Web/Website } \\
\hline 1 & Indonesia/Indonesia & http://www.jdih.pom.go.id \\
& & http://www.sni.bsn.go.id \\
2 & Codex Alimentariurs Commision (CAC) & http://www.fao.org/fao-who-codexalimentarius/codex-texts/list- \\
& & standards/en/ \\
3 & Uni Eropa/European Union & https://eur-lex.europa.eu/homepage.html \\
4 & Kanada/Canada & http://www.inspection.gc.ca/about-the-cfia/acts-and-regulations/list-of- \\
& & acts-and-regulations/eng/1419029096537/1419029097256 \\
5 & China/China & http://eng.sfda.gov.cn/WSO3/CL0755/ \\
6 & Korea Selatan/South Korea & http://www.mfds.go.kr/eng/index.do?nMenuCode=110 \\
7 & Vietnam/Vietnam & http://www.nafiqad.gov.vn \\
8 & Amerika Serikat/United States of America & https://www.fda.gov \\
9 & Jepang/Japan & https://www.mhlw.go.jp/english/ \\
10 & Malaysia/Malaysia & http://www.jsm.gov.my \\
11 & Singapura/Singapore & http://www.ava.gov.sg \\
12 & Thailand/Thailand & http://www.fda.moph.go.th/sites/fda_en/Pages/Main.aspx \\
13 & Australia/Australia & http://www.foodstandards.gov.au/Pages/default.aspx
\end{tabular}

pembanding. Alamat situs web setiap standar tersebut dapat dilihat pada Tabel 1.

\section{Kaji banding standar cemaran kimia produk perikanan Indonesia dengan negara lain dan Codex}

Terhadap dokumen standar cemaran yang diperoleh, dilakukan identifikasi dan perbandingan komponen kriteria cemaran kimia dari Indonesia dan negara-negara lain serta menganalisis pemenuhan kriteria yang dibandingkan dengan standar CAC. Analisis standar cemaran kimia pada produk perikanan yang mendapat notifikasi penolakan ekspor dengan frekuensi tinggi yang meliputi jenis cemaran dan jenis produk perikanan dilakukan dengan membandingkan standar-standar cemaran kimia produk perikanan tersebut dengan CAC, serta negaranegara lainnya. Hal-hal yang dianalisis meliputi: 1) nama cemaran, 2) singkatan atau simbol sesuai dengan deskripsi yang digunakan, 3) rujukan pada JECFA meetings sesuai dengan jenis kontaminan yang dievaluasi dan tahun diselenggarakannya pembahasan tersebut, 4) informasi toksikologi cemaran terkait level atau tingkatan yang dapat ditoleransi oleh manusia, yang dinyatakan dalam setiap kg berat tubuh (bw) serta tahun rekomendasinya dan penjelasanpenjelasan lain yang ditambahkan, 5) definisi cemaran yang dapat dianalisis sehingga menentukan batas maksimum dan penerapan batas pengolahannya, 6 ) referensi atau rujukan terkait pengolahan pangan untuk mencegah terjadinya kontaminasi atau informasiinformasi lain tentang sumber cemaran, dan 7) nilai ambang batas atau level yang diperbolehkan terhadap cemaran tersebut. Selain itu terdapat parameter atau komponen-komponen antara lain: jenis pangan, nilai batas maksimum, jumlah atau porsi dari produk pangan yang dapat dikonsumsi, dan informasi tambahan.

\section{Penyusunan rekomendasi penetapan standar cemaran kimia pada produk perikanan di Indonesia}

Atas hasil analisis dan kaji banding terhadap standar cemaran yang ada maka dilakukan penyusunan rekomendasi penerapan standar cemaran kimia pada produk perikanan di Indonesia, termasuk bila diperlukan perbaikan atau perubahan. Rekomendasi ini dapat digunakan sebagai dasar penetapan standar cemaran kimia di Indonesia sehingga dapat memenuhi kriteria yang ditetapkan oleh CAC maupun negara-negara importir. Rekomendasi ini meliputi beberapa aspek, antara lain standar kontaminan pada pangan, penetapan standar logam berat pada produk perikanan serta penetapan standar benzo[a]piren pada produk perikanan.

\section{HASIL DAN PEMBAHASAN}

\section{Jenis Cemaran dan Komoditas Perikanan dengan Notifikasi Penolakan Tertinggi}

Penerapan sistem jaminan mutu dan keamanan hasil perikanan di Indonesia telah diakui kesetaraannya oleh negara-negara tujuan ekspor produk perikanan 
Indonesia. Pengakuan kesetaraan tersebut dituangkan dalam bentuk perjanjian kerjasama ekspor impor produk perikanan (Mutual Recognition Arrangements/ MRA) antara Indonesia dengan negara tujuan ekspor. Indonesia telah menjalin hubungan kerjasama dengan 7 negara sejak tahun 1994, negara mitra tersebut yaitu Uni Eropa (Commision Decision No. 94/324/EC of 19 May 1994 laying down Special Conditions Governing Imports of Fishery and Aquaculture Products Originating in Indonesia), Kanada (Arrangement on the Mutual Recognition of Fish and Fishery Products Inspection and Control Systems pada tanggal 7 Maret 2002), Korea Selatan (Arrangement on the Cooperation in Quality Control and Hygiene Safety of Import and Export Fish and Fishery Products pada tanggal 15 September 2005), China (Cooperation Agreement on Safety Assurance in the Import and Export of Aquatic Products pada tanggal 11 November 2008), Rusia (Arrangement on Quality Control and Hygiene Safety of Import and Export Fish and Fishery Products pada tanggal 23 April 2009), Vietnam (Implementing Arrangement on Quality and Food Safety Control of Fish and Fishery Products pada tanggal 22 September 2011), dan Norwegia (Mutual Recognition Arrangement on Quality and Food Safety of Fish and Fishery Products pada tanggal 11
September 2013). Salah satu keuntungan adanya pengakuan kesetaraan tersebut adalah adanya pertukaran informasi dalam bentuk notifikasi antar negara mitra jika terjadi kasus penolakan ekspor produk perikanan.

Selama periode tahun 2008-2017, penolakan produk perikanan terjadi di 3 (tiga) negara mitra yaitu: Uni Eropa, Kanada dan Korea Selatan sebesar 164 kasus penolakan, sedangkan untuk negara Vietnam dan China tidak ada penolakan produk perikanan. Data penolakan produk perikanan ini dihitung berdasarkan adanya notifikasi resmi yang masuk ke Otoritas Kompeten. Secara lebih terperinci penyebab penolakan terdapat pada Gambar 1. Di antara 164 kasus tersebut terdapat 53 kasus (32\%) karena adanya cemaran logam berat pada produk perikanan. Cemaran logam berat yang mengontaminasi produk perikanan tertinggi adalah merkuri sebesar $23 \%$. Cemaran merkuri dan metilmerkuri (4\%) banyak terdapat pada ikan todak (Xiphias gladius), cemaran cadmium sebesar $5 \%$ terdapat pada gurita, dan cemaran arsen sebesar 1\% terdapat pada tuna. Kontaminan kimia lain yang terdapat pada produk perikanan adalah benzo[a]piren sebesar 3\% yang terdapat pada ikan asap serta antibiotik sebanyak $4 \%$

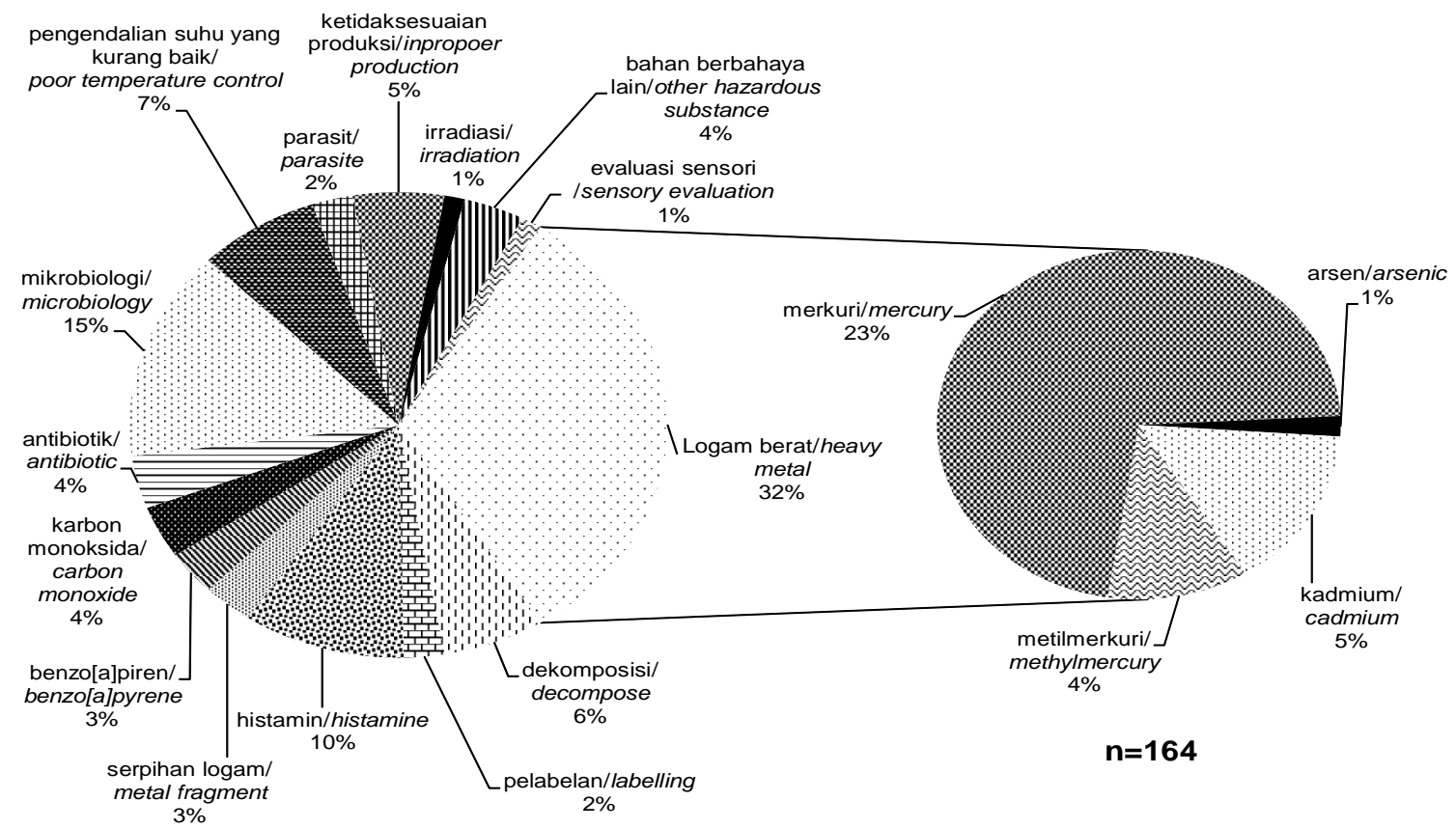

Sumber: Data yang diolah oleh Pusat Pengendalian Mutu-BKIPM, KKP (2018)

Source: Data Processed by Center for Quality and Safety Control-FQIA, MMAF (2018)

Gambar 1. Penyebab kasus penolakan produk perikanan Indonesia tahun 2008-2017 oleh Uni Eropa (116 notifikasi), Kanada (19 notifikasi), dan Korea Selatan (29 notifikasi)

Figure1. Causes of rejection of Indonesian fishery products in 2008-2017 in European Union (116 notification), Canada (19 notification) and South Korea (29 notification) 
pada produk udang dan daging rajungan. Metilmerkuri terkonsentrasi pada satu tingkat rantai makanan pada jejaring makanan ikan dan ikan predator menempati tingkat rantai makanan tertinggi sehingga cenderung memiliki konsentrasi metil merkuri yang tinggi. Sadhu et al. (2015) dalam penelitiannya menyebutkan bahwa secara umum ikan predator memiliki kandungan metil merkuri yang tinggi. Sebagai contoh ikan predator antara lain ikan ling, tuna albakor, dan jenis-jenis ikan hiu. Konsentrasi metilmerkuri terdapat pada ikan ling yaitu sebesar 2,40 $\pm 016 \mu \mathrm{g} \mathrm{MeHg} / \mathrm{g}$ (Sadhu et al., 2015). Ikan ling tergolong dalam ikan predator yang memakan segala jenis ikan, gurita, cumi-cumi, udang dan kepiting.

Penolakan produk perikanan Indonesia di Uni Eropa selama tahun 2008-2017 disebabkan oleh beberapa faktor. Penyebab penolakan produk perikanan di Uni Eropa selama periode tahun 2008-2017 sebagian besar disebabkan oleh adanya cemaran logam berat sebanyak 45 notifikasi pada produk marlin, ikan todak, gurita, cumi-cumi, dan ikan kakap. Tren penolakan produk perikanan Indonesia di Uni Eropa berdasarkan penyebab penolakan tersaji pada Tabel 2. Tren penolakan produk perikanan Indonesia di Kanada tahun 2008-2017 tersaji pada Tabel 3. Selama periode tahun 2008-2012, tidak terdapat penolakan produk perikanan Indonesia di Kanada. Mayoritas penyebab penolakan produk perikanan di Kanada disebabkan karena dekomposisi. Berdasarkan hasil investigasi yang dilakukan oleh BKIPM-KKP, bahwa sebagian besar eksportasi ke Kanada dari Indonesia dilakukan melalui Amerika Serikat dan perusahaan perikanan Indonesia tidak mengetahui bahwa produk perikanan yang di ekspor ke Amerika Serikat di ekspor lagi oleh pembeli ke Kanada.

Penolakan produk perikanan Indonesia di Korea tahun 2008-2017 tersaji pada Tabel 4. Mayoritas penyebab penolakan produk perikanan di Korea disebabkan oleh logam berat, yang selanjutnya disebabkan karena mikrobiologi, benzo[a]piren dan adanya serpihan logam pada produk. Salah satu produk perikanan yang banyak diekspor ke Korea adalah ikan kayu, di mana proses pembuatannya dilakukan dengan metode pengasapan.

Tabel 2. Tren penolakan produk perikanan Indonesia di Uni Eropa berdasarkan penyebab penolakan pada tahun 2008-2017

Table 2. The rejection trend of Indonesian fishery products in the European Union based on the causes of rejection in 2008-2017

\begin{tabular}{|c|c|c|c|c|c|c|c|c|c|c|}
\hline \multirow{2}{*}{$\begin{array}{l}\text { Alasan penolakan/ } \\
\text { Cause of rejection }\end{array}$} & \multicolumn{10}{|c|}{ Tahun/Year } \\
\hline & 2008 & 2009 & 2010 & 2011 & 2012 & 2013 & 2014 & 2015 & 2016 & 2017 \\
\hline $\begin{array}{l}\text { Karbon monoksida/ } \\
\text { Carbon monoxide }\end{array}$ & - & - & 1 & 1 & - & - & - & - & - & 1 \\
\hline Logam berat/Heavy metal & 4 & 3 & 5 & 4 & 2 & 5 & 4 & 4 & 5 & 9 \\
\hline Histamin/Histamine & 1 & - & 2 & - & 2 & 3 & 5 & - & - & 2 \\
\hline Antibiotik/Antibiotic & 1 & 1 & - & - & 1 & - & - & - & - & - \\
\hline Mikrobiologi/Microbiology & - & - & 1 & - & 15 & - & 1 & - & 1 & - \\
\hline Organoleptik/Organoleptic & - & - & 1 & - & - & - & - & - & - & - \\
\hline $\begin{array}{l}\text { Peningkatan } \\
\text { Suhu/Increase of } \\
\text { Temperature }\end{array}$ & 1 & - & 1 & 1 & 5 & 1 & - & - & 1 & 3 \\
\hline Parasit/Parasite & 1 & 3 & - & - & - & - & - & - & - & - \\
\hline Irradiasi//Irradiation & - & 1 & 1 & - & - & - & - & - & - & - \\
\hline $\begin{array}{l}\text { Ketidaksesuaian } \\
\text { produksi/Inproper of } \\
\text { production }\end{array}$ & - & - & 3 & - & - & - & - & 2 & - & - \\
\hline Lain-lain/Others & - & 3 & - & 1 & - & - & - & 2 & 1 & - \\
\hline Total & 8 & 11 & 15 & 7 & 25 & 9 & 10 & 8 & 8 & 15 \\
\hline
\end{tabular}

Sumber: Situs RASFF Portal yang diolah; Source: RASFF Portal website

Keterangan: (-) tidak ada penolakan/no rejection data 
Tabel 3. Tren penolakan produk perikanan Indonesia di Kanada berdasarkan penyebab penolakan pada tahun 2013-2017

Table 3. The rejection trend of Indonesian fishery products in Canada based on the causes of rejection in 2013-2017

\begin{tabular}{lcccccc}
\hline \multicolumn{1}{c}{$\begin{array}{c}\text { Alasan penolakan/ } \\
\text { Cause of rejection }\end{array}$} & $\mathbf{2 0 1 3}$ & $\mathbf{2 0 1 4}$ & $\mathbf{2 0 1 5}$ & $\mathbf{2 0 1 6}$ & $\mathbf{2 0 1 7}$ & $\begin{array}{c}\text { Jumlah/ } \\
\text { Amount }\end{array}$ \\
\cline { 2 - 7 } & 9 & - & - & - & 1 & 10 \\
Dekomposisi/Decompose & - & 1 & - & - & - & 1 \\
Histamin/Histamine & - & 2 & - & - & - & 2 \\
Kurang berat/Lack of weight & - & 1 & 1 & - & 1 & 3 \\
$\begin{array}{l}\text { Bahan tambahan } \\
\text { berbahaya/Hazardous additives }\end{array}$ & - & - & - & 2 & - & 2 \\
Evaluasi sensori/Sensory evaluation & - & - & - & - & 1 & 1 \\
Merkuri/Mercury & - & 4 & 1 & 2 & 3 & 19 \\
Total & 9 & &
\end{tabular}

Sumber/Source: Pusat Pengendalian Mutu-KKP/Center for Quality and Safety Control

Keterangan/Note: (-): tidak ada penolakan/no rejection data

Tabel 4. Tren penolakan produk perikanan Indonesia di Korea Selatan berdasarkan penyebab penolakan pada tahun 2008-2017

Table 4. The rejection trend of Indonesian fishery products in South Korea based on the causes of rejection in 2008-2017

\begin{tabular}{lccccccccccc}
\hline \multicolumn{1}{c}{$\begin{array}{l}\text { Alasan penolakan/ } \\
\text { Cause of rejection }\end{array}$} & \multicolumn{10}{c}{ Tahun/Year } & Jumlah/ \\
\cline { 2 - 10 } & $\mathbf{2 0 0 8}$ & $\mathbf{2 0 0 9}$ & $\mathbf{2 0 1 0}$ & $\mathbf{2 0 1 1}$ & $\mathbf{2 0 1 2}$ & $\mathbf{2 0 1 3}$ & $\mathbf{2 0 1 4}$ & $\mathbf{2 0 1 5}$ & $\mathbf{2 0 1 6}$ & $\mathbf{2 0 1 7}$ & Amount \\
\hline Serpihan logam/Metal fragment & 5 & - & - & - & - & - & - & - & - & - & 5 \\
Mikrobiologi/Microbiology & 1 & 2 & 1 & - & - & - & - & - & - & 1 & 5 \\
Logam berat/Heavy metal & - & 1 & 3 & 1 & - & 1 & - & 1 & - & - & 7 \\
Benzo[a]piren/Benzo[a]pyrene & - & - & - & - & 1 & 2 & - & - & 2 & - & 5 \\
Karbon monoksida/Carbon & - & 1 & - & 1 & 1 & - & - & - & 1 & - & 4 \\
monoxide & - & 1 & - & - & - & - & 2 & - & - & - & 3 \\
Antibiotik/Antibiotic & 6 & 5 & 4 & 2 & 2 & 3 & 2 & 1 & 3 & 1 & 29 \\
Total & & &
\end{tabular}

Sumber/Source: Pusat Pengendalian Mutu-KKP/Center for Quality and Safety Control

Keterangan/Note: (-) tidak ada penolakan/no rejection data

\section{Perbedaan Standar Cemaran Kimia pada Produk Perikanan di Indonesia, CAC dan Negara-negara Lain Terhadap Ikan Todak, Gurita, dan Ikan Asap}

Setiap negara memiliki standar cemaran kimia yang berbeda-beda. Tujuan penetapan standar cemaran kimia pada suatu negara yaitu merupakan alat bagi pemerintah untuk upaya pengawasan sistem keamanan pangan. Tabel 5 menunjukkan peraturan dan pustaka standar cemaran kimia dari negara lainnya. Indonesia dan negara lainnya menerbitkan dan mengamandemen peraturan terkait cemaran kimia setelah tahun 1995, saat CAC menerbitkan
General Standard for Contaminants and Toxins in Food and Feed (CODEX STAN 193-1995). Uni Eropa melakukan beberapa perubahan atau amandemen terkait batas maksimum cemaran kimia pada produk perikanan, dan membuat regulasi khusus untuk beberapa cemaran kimia misalnya kadmium, timbal, dan polycyclic aromatic hydrocarbon (PAH). Indonesia mengatur batas maksimum cemaran logam berat dalam pangan olahan melalui Peraturan Kepala BPOM Nomor 5 tahun 2018, dan juga tertuang dalam SNI 7387:2009; serta terdapat pada Peraturan Kepala BPOM Nomor 8 tahun 2018 dan SNI 7501:2009 terkait peraturan batas maksimum cemaran kimia dalam pangan olahan. 
Tabel 5. Peraturan dan pustaka standar cemaran kimia di Indonesia dan negara lain Table 5. Regulation of contaminant standard in Indonesia and other countries

\begin{tabular}{|c|c|c|c|c|}
\hline $\begin{array}{l}\text { No/ } \\
\text { No. }\end{array}$ & $\begin{array}{l}\text { Negara/ } \\
\text { Country }\end{array}$ & & $\begin{array}{c}\text { Judul Pustaka/ } \\
\text { Literature }\end{array}$ & $\begin{array}{c}\text { Sumber Pustaka/ } \\
\text { Reference }\end{array}$ \\
\hline \multirow[t]{3}{*}{1} & $\begin{array}{l}\text { Indonesia/ } \\
\text { Indonesia }\end{array}$ & 1. & $\begin{array}{l}\text { SNI 7387:2009 tentang Batas Maksimum Cemaran Logam Berat } \\
\text { dalam Pangan } \\
\text { SNI 7501:2009 tentang Batas Maksimum Cemaran Kimia } \\
\text { (benzo[a]piren, dioksin (2,3,7,8-TCDD), 1,3-dikloropropan-2-ol (1,3- } \\
\text { DCP), dan 3-monokloropropan-1,2-diol (3-MCPD)) dalam pangan }\end{array}$ & $\begin{array}{l}\text { Badan Standardisasi Nasional, } \\
2009\end{array}$ \\
\hline & & 3. & $\begin{array}{l}\text { Peraturan Kepala BPOM Nomor } 5 \text { Tahun } 2018 \text { tentang Batas } \\
\text { Maksimum Cemaran Logam Berat dalam Pangan Olahan }\end{array}$ & BPOM, 2018 \\
\hline & & 4. & $\begin{array}{l}\text { Peraturan Kepala BPOM Nomor } 8 \text { Tahun } 2018 \text { tentang Batas } \\
\text { Maksimum Cemaran Kimia dalam Pangan Olahan }\end{array}$ & BPOM, 2018 \\
\hline 2 & $\begin{array}{l}\text { Codex } \\
\text { Alimentariurs } \\
\text { Commision (CAC) }\end{array}$ & 1. & $\begin{array}{l}\text { General Standard for Contaminants and Toxins in Food and Feed } \\
\text { (Codex Stan 193-1995) }\end{array}$ & CAC, 1995 \\
\hline \multirow[t]{7}{*}{3} & $\begin{array}{l}\text { Uni Eropa/ } \\
\text { European Union }\end{array}$ & 1. & $\begin{array}{l}\text { Commision Regulation (EC) No. } 1881 / 2006 \text { of } 19 \text { December } 2006 \\
\text { on Setting maximum levels for certain contaminants in foodstuffs }\end{array}$ & European Commision, 2006 \\
\hline & & 2. & $\begin{array}{l}\text { Commision Regulation (EC) No. } 420 / 2011 \text { of } 29 \text { April } 2011 \\
\text { amending Regulation (EC) No. } 1881 / 2006 \text { on Setting maximum } \\
\text { levels for certain contaminants in foodstuffs }\end{array}$ & European Commision, 2011 \\
\hline & & 3. & $\begin{array}{l}\text { Commision Regulation (EC) No. 629/2008 of } 2 \text { July } 2008 \text { amending } \\
\text { Regulation (EC) No. } 1881 / 2006 \text { on Setting maximum levels for } \\
\text { certain contaminants in foodstuffs }\end{array}$ & European Commision, 2008 \\
\hline & & 4. & $\begin{array}{l}\text { Commision Regulation (EC) No. 488/2014 of } 12 \text { May } 2014 \\
\text { amending Regulation (EC) No. } 1881 / 2006 \text { as regard maximum } \\
\text { levels of Cadmium in foodstuffs }\end{array}$ & European Commision, 2014 \\
\hline & & 5. & $\begin{array}{l}\text { Commision Regulation (EC) No. 2015/1005 of } 25 \text { June } 2015 \\
\text { amending Regulation (EC) No. 1881/2006 as regard maximum } \\
\text { levels of Lead in Certain foodstuffs }\end{array}$ & European Commision, 2015 \\
\hline & & 6. & $\begin{array}{l}\text { Commision Regulation (EC) No. 2015/1125 of } 10 \text { July } 2015 \\
\text { amending Regulation (EC) No. 1881/2006 as regard maximum } \\
\text { levels for polycyclic aromatic hydrocarbons in Katsuobushi (dried } \\
\text { bonito) and certain smoked Baltic herring }\end{array}$ & European Commision, 2015 \\
\hline & & 7. & $\begin{array}{l}\text { Commision Regulation (EC) No. 1327/2014 of } 12 \text { December } 2014 \\
\text { amending Regulation (EC) No. } 1881 / 2006 \text { as regard maximum } \\
\text { levels of polycyclic aromatic hydro carbons (PAHs) in traditionally } \\
\text { smoked meat and meat products and traditionally smoked fish and } \\
\text { fishery products }\end{array}$ & European Commision, 2014 \\
\hline 4 & Kanada/Canada & 1. & List of contaminants and other adulterating substances in foods & Health Canada, 2018 \\
\hline 5 & China/China & 1. & $\begin{array}{l}\text { National food safety standard of maximum levels of contaminants in } \\
\text { foods (GB 2762-2012) }\end{array}$ & $\begin{array}{l}\text { The National Health and Family } \\
\text { Planning of People's Republic of } \\
\text { China (NFHPC), } 2012\end{array}$ \\
\hline 6 & $\begin{array}{l}\text { Korea Selatan/ } \\
\text { South Korea }\end{array}$ & 1. & Food Code & $\begin{array}{l}\text { Ministry of Food and Drug } \\
\text { Safety, } 2017\end{array}$ \\
\hline \multirow[t]{2}{*}{7} & Vietnam/Vietnam & 1. & $\begin{array}{l}\text { National technical regulation on the limits of heavy metals } \\
\text { contamination in food, QCVN 8-2:2011/BYT }\end{array}$ & Ministry of Health, 2011 \\
\hline & & 2. & $\begin{array}{l}\text { National technical regulation on maximum level of mycotoxin } \\
\text { allowed in food, QCVN 8-1:2011/BYT }\end{array}$ & Ministry of Health, 2011 \\
\hline 8 & $\begin{array}{l}\text { Amerika Serikat/ } \\
\text { United States of } \\
\text { America }\end{array}$ & 1. & $\begin{array}{l}\text { Action level for Poisonous or deleterious substances in human food } \\
\text { and animal feed }\end{array}$ & $\begin{array}{l}\text { Food and Drug Administration } \\
\text { (FDA), } 2010\end{array}$ \\
\hline 9 & Jepang/Japan & 1. & $\begin{array}{l}\text { Specifications and standards for food, food additive, etc Under the } \\
\text { Food Sanitation Act (Abstract) } 2010\end{array}$ & $\begin{array}{l}\text { Japan External Trade } \\
\text { Organization (JETRO), } 2011\end{array}$ \\
\hline 10 & Malaysia/Malaysia & 1. & $\begin{array}{l}\text { Food Regulation } 1985 \\
\text { Standards of Malaysia Act } 1996 \text { (Act 549) }\end{array}$ & $\begin{array}{l}\text { Ministry of Health, } 1985 \\
\text { Ministry of Science, Technology } \\
\text { and Innovation, } 2012\end{array}$ \\
\hline 11 & $\begin{array}{l}\text { Singapura/ } \\
\text { Singapore }\end{array}$ & 1. & Sale of Food Act (Chapter 283, Section 56(1)), Food Regulation & $\begin{array}{l}\text { Agri-Food and Veterinary } \\
\text { Authority, } 2005\end{array}$ \\
\hline 12 & Thailand/Thailand & $\begin{array}{l}1 . \\
2 .\end{array}$ & $\begin{array}{l}\text { Notification of the Ministry of Public Health No. } 98 \text { (B.E.2529): } \\
\text { Prescribing Standards of Contaminated Substances } \\
\text { Notification of the Ministry of Public Health No. } 273 \text { (B.E.2546): } \\
\text { Standards of Contaminants in Food (No.2) }\end{array}$ & Ministry of Public Health, 2003 \\
\hline 13 & $\begin{array}{l}\text { Australia dan } \\
\text { Selandia Baru/ } \\
\text { Australia and New } \\
\text { Zealand }\end{array}$ & 1. & $\begin{array}{l}\text { Food standard Australia New Zealand Act (Schedule 19. Maximum } \\
\text { level of contaminants and natural toxicants) }\end{array}$ & $\begin{array}{l}\text { Food Standards Australia and } \\
\text { New Zealand, } 2017\end{array}$ \\
\hline
\end{tabular}


Berdasarkan standar cemaran kimia di 12 negara tersebut, setiap negara memiliki pengelompokan jenis produk perikanan yang berbeda-beda. Terdapat 8 (delapan) negara yang membedakan batas maksimum cemaran logam berat terhadap jenis ikan predator dan non predator. Namun, penentuan jenis ikan yang tergolong dalam ikan predator ditentukan oleh masingmasing negara. Sebagai contoh adalah Kanada, yang menetapkan ikan hiu, todak, dan tuna sirip biru ke dalam golongan ikan predator (Bentley \& Soebandrio 2017). Terdapat 2 (dua) negara yang menetapkan batas maksimum terhadap pangan secara umum. Uni Eropa menetapkan batas maksimum cemaran kimia melalui 7 (tujuh) peraturan dengan mengatur masingmasing cemaran kimia dengan spesies ikan tertentu yang lebih spesifik (Tabel 7).
Codex Alimentarius Commision merupakan badan antar pemerintah yang melaksanakan program standar pangan FAO/WHO. CAC dibentuk dengan tujuan untuk melindungi kesehatan konsumen, menjamin praktik perdagangan pangan internasional yang jujur serta mempromosikan koordinasi standardisasi pangan yang dilakukan oleh organisasi internasional lainnya. CAC menetapkan dokumendokumen yang berupa standar, pedoman, code of practice, dan rekomendasi lainnya yang mencakup bidang pangan, ketentuan bahan tambahan dan kontaminan pangan, batas maksimum residu pestisida dan residu obat hewan, prosedur sertifikasi dan inspeksi serta metoda analisis dan sampling (BSN 2018). Indonesia dan 11 negara lainnya termasuk dalam anggota $\mathrm{CAC}$ berdasarkan data yang terdapat

Tabel 6. Pemenuhan kriteria/elemen pada standar cemaran kimia dibandingkan dengan CAC Table 6. Compliance of criteria for the contaminant's standard compared to CAC

\begin{tabular}{|c|c|c|c|c|c|c|c|c|c|c|c|c|c|c|}
\hline \multirow{2}{*}{\multicolumn{2}{|c|}{$\begin{array}{c}\text { Kriteria pada cemaran } \\
\text { kimia/Element in Chemical } \\
\text { Contaminants }\end{array}$}} & \multicolumn{12}{|c|}{ Negara/Country } & \multirow{3}{*}{$\frac{\text { CAC }}{\sqrt{ }}$} \\
\hline & & \multirow{2}{*}{$\begin{array}{c}\begin{array}{c}\text { Ind } \\
\text { (SNI) }\end{array} \\
\text { TS }\end{array}$} & \multirow{2}{*}{ Viet } & \multirow{2}{*}{$\begin{array}{l}\text { Tha } \\
\text { TS }\end{array}$} & \multirow{2}{*}{$\frac{\operatorname{Sin}}{\mathrm{TS}}$} & \multirow{2}{*}{$\begin{array}{c}\text { Mal } \\
\mathrm{S}\end{array}$} & \multirow{2}{*}{$\frac{\text { Chn }}{\mathrm{S}}$} & \multirow{2}{*}{$\begin{array}{c}\text { Jpn } \\
\text { TS }\end{array}$} & \multirow{2}{*}{ Kor } & \multirow{2}{*}{$\begin{array}{c}\text { USA } \\
\text { TS }\end{array}$} & \multirow{2}{*}{$\begin{array}{l}\text { Can } \\
\text { TS }\end{array}$} & \multirow{2}{*}{$\begin{array}{l}\text { Aus } \\
\text { TS }\end{array}$} & \multirow{2}{*}{$\begin{array}{c}\text { EU } \\
\text { TS }\end{array}$} & \\
\hline 1 & $\begin{array}{l}\text { Nama cemaran/kind of } \\
\text { contaminants }\end{array}$ & & & & & & & & & & & & & \\
\hline 2 & $\begin{array}{l}\text { Singkatan atau } \\
\text { symbol/abbreviation or } \\
\text { symbol }\end{array}$ & $\mathrm{S}$ & $\mathrm{S}$ & $\mathrm{S}$ & $\mathrm{S}$ & $\mathrm{S}$ & $\mathrm{S}$ & $\mathrm{S}$ & $\mathrm{S}$ & $\mathrm{S}$ & S & $S$ & $S$ & $\sqrt{ }$ \\
\hline 3 & $\begin{array}{l}\text { Rujukan pada JECFA } \\
\text { meetings/reference to } \\
\text { JECFA meetings }\end{array}$ & - & - & - & - & - & - & - & - & - & $\sqrt{ }$ & - & $\sqrt{ }$ & $\sqrt{ }$ \\
\hline 4 & $\begin{array}{l}\text { Informasi toksikologi } \\
\text { cemaran/information of } \\
\text { contaminants toxicology }\end{array}$ & $\sqrt{ }$ & $\sqrt{ }$ & - & - & - & - & - & - & $\sqrt{ }$ & $\sqrt{ }$ & $\sqrt{ }$ & $\sqrt{ }$ & $\sqrt{ }$ \\
\hline 5 & $\begin{array}{l}\text { Definisi } \\
\text { cemaran/contaminants } \\
\text { definition }\end{array}$ & $\sqrt{ }$ & $\sqrt{ }$ & - & - & - & - & - & $\sqrt{ }$ & - & - & $\sqrt{ }$ & $\sqrt{ }$ & $\sqrt{ }$ \\
\hline 6 & $\begin{array}{l}\text { Referensi terkait } \\
\text { pengolahan pangan } \\
\text { untuk mencegah } \\
\text { terjadinya } \\
\text { kontaminan/reference for } \\
\text { the processing to avoid a } \\
\text { contaminant }\end{array}$ & $\sqrt{ }$ & $\sqrt{ }$ & - & - & - & $\sqrt{ }$ & - & - & $\sqrt{ }$ & $\sqrt{ }$ & - & $\sqrt{ }$ & $\sqrt{ }$ \\
\hline 7 & $\begin{array}{l}\text { Nilai ambang batas yang } \\
\text { diperbolehkan terhadap } \\
\text { cemaran/Maximum level } \\
\text { of contaminant }\end{array}$ & $\sqrt{ }$ & $\sqrt{ }$ & $\sqrt{ }$ & $\sqrt{ }$ & $\sqrt{ }$ & $\sqrt{ }$ & $\sqrt{ }$ & $\sqrt{ }$ & $\sqrt{ }$ & $\sqrt{ }$ & $\sqrt{ }$ & $\sqrt{ }$ & $\sqrt{ }$ \\
\hline
\end{tabular}

Keterangan/note:

TS : Tidak sesuai dengan CAC/Not comply with CAC

$\mathrm{S}$ : Sesuai dengan CAC/Comply with CAC

Ind : Indonesia/Indonesia

Viet: Vietnam/Vietnam

Tha: Thailand/Thailand

Sin : Singapura/Singapore

Mal : Malaysia/Malaysia

Chn: China/China
(V) : Tersedia/Available

(-) : Tidak tersedia/Not available

Jpn : Jepang/Japan

Kor : Korea Selatan/South Korea

USA: Amerika Serikat/United States of America

Can : Kanada/Canada

Aus : Australia/Australia

EU : Uni Eropa/European Union 
pada laman CAC. Berdasarkan sandingan pemenuhan kriteria cemaran kimia yang diatur di tiap negara (Tabel 6), tidak seluruh kriteria berdasarkan CAC diikuti oleh 12 negara tersebut. Pengelompokan jenis cemaran pada ke-12 negara tersebut tidak seluruhnya sesuai dengan standar CAC, namun seluruh negara memenuhi kriteria singkatan atau simbol serta telah terdapat nilai ambang batas atau level yang diperbolehkan terhadap suatu cemaran.

Shao, Wang, Chen, dan Wu (2014) menyebutkan bahwa di China, terdapat 608 standar komoditas pangan yang akan dikonsolidasikan/ditelaah, yang terbagi dalam 197 standar nasional dan 411 standar dagang. Selain itu, terdapat 17 kontaminan yang diseleksi sesuai dengan beberapa kriteria yaitu, telah terdapat batas maksimum pada sistem standar pangan dan terdapat pula pada standar CAC. Kontaminan yang diatur tersebut antara lain: kontaminan anorganik (selenium, florin, aluminium, timbal, arsen, merkuri, cadmium, nikel, tin, kromium, nitrat, dan nitrit) serta kontaminan organik (benzo[a]piren, nitrosamine, Polychlorinated Biphenyls (PCBs), dan kloropropanol.

Terkait informasi toksikologi cemaran kimia yang dinyatakan dalam setiap unit berat tubuh (bw) dan referensi atau rujukan terkait pengolahan pangan untuk mencegah terjadinya kontaminasi atau informasiinformasi lain terkait cemaran, sebanyak 50\% dari 12 negara telah melakukan pengaturan. Mayoritas negara tidak mencantumkan rujukan pada pembahasan Joint FAO/WHO Expert Committtee on Food Additives (JECFA) meeting dalam standar batas maksimum cemaran kimia. Uni Eropa tidak secara langsung mencantumkan rujukan JECFA meeting dalam dokumen standar kontaminan. Informasi keikutsertaan Uni Eropa dalam pembahasan tersebut terdapat dalam laman informasi Otoritas Keamanan Pangan Uni Eropa atau European Food Safety Authority (EFSA).

Peraturan yang menetapkan batas maksimum cemaran kimia pada produk pangan di Indonesia terdapat pada SNI dan Peraturan Kepala BPOM. SNI menetapkan batas maksimum logam berat pada tahun 2009 dengan nomor SNI 7387:2009, sedangkan BPOM menetapkan batas maksimum logam berat pada tahun 2018, dengan merevisi peraturan sebelumnya tahun 2017 dengan mengikuti perkembangan ilmu pengetahuan yang ada. Berdasarkan pada Tabel 6, SNI lebih banyak dalam memenuhi kriteria CAC, sedangkan Peraturan Kepala BPOM memenuhi kriteria CAC sebesar $25 \%$.

\section{Standar Logam Berat}

CAC menetapkan batas maksimum cemaran kimia kadmium, timbal, dan metilmerkuri untuk produk perikanan. Indonesia menetapkan batas maksimum cemaran arsen, kadmium, timbal, dan merkuri. Mayoritas negara-negara menetapkan batas maksimum cemaran merkuri, sedangkan CAC menetapkan batas metilmerkuri. Namun, Jepang, Vietnam, dan Korea Selatan menetapkan batas maksimum cemaran merkuri dan metilmerkuri untuk produk perikanan. Beberapa negara (Indonesia, Thailand, Singapura, Malaysia, China, Kanada, dan Australia dan Selandia Baru) juga menetapkan batas maksimum arsen untuk produk perikanan, sehingga perlindungan terhadap konsumen dapat lebih optimal.

CAC menetapkan metode pengujian cemaran kimia yang tercantum dalam general methods of analysis for contaminants (CODEX STAN 228-2001). CAC menetapkan metode pengujian terhadap timbal, seng, dan tembaga dengan menggunakan prinsip spektrofotometer serapan atom/atomic absorbsion spektrophotometri (AAS), sedangkan pengujian kadmium menggunakan prinsip anodic stripping voltametry. Uni Eropa menetapkan metode pengujian logam berat seperti yang terangkum didalam official methods for the determination of heavy metals in feed and food (European Commission, 2012). Uni Eropa menetapkan 3 (tiga) standar pengujian yaitu berdasarkan CEN publish standards, metode analisis AOAC, dan metode ISO. Selanjutnya, Uni Eropa menetapkan standar pengujian untuk kadmium, timbal, arsen, merkuri, metilmerkuri, seng, dan tembaga. Untuk pengujian merkuri menggunakan spektrofotometer serapan atom dengan nyala/flame AAS, sedangkan metode pengujian metilmerkuri untuk ikan dan kekerangan menggunakan gas chromatography (GC).

Indonesia melalui SNI 2354.5:2011 menetapkan cara penentuan kadar logam berat timbal $(\mathrm{Pb})$ dan kadmium ( $\mathrm{Cd}$ ) pada produk perikanan dengan menggunakan metode AAS (Atomic Absorption Spectroscopy), sedangkan cara pengujian kadar merkuri pada produk perikanan diatur dalam SNI 2354.6:2016 dengan menggunakan metode spektrofotometer serapan atom tanpa nyala/flameless AAS. Negara-negara lain tidak menetapkan standar metode pengujian cemaran kimia secara terpisah, sehingga pengujian cemaran kimia mengacu pada standar CAC atau ISO (Tabel 7).

Berdasarkan notifikasi penolakan produk perikanan Indonesia di Uni Eropa, Kanada, dan Korea Selatan, cemaran kimia yang mendominasi penolakan produk perikanan antara lain merkuri dan metilmerkuri, cadmium dan benzo[a]piren. $\mathrm{Hg}$ adalah salah satu logam berat yang beracun yang terdapat pada lingkungan. Sumber utama terpaparnya manusia oleh merkuri adalah melalui konsumsi ikan baik ikan air tawar maupun ikan air laut yang kandungan merkurinya terakumulasi pada ikan melalui biomagnifasi pada rantai makanan (Stojanovic et al., 
Tabel 7. Jenis cemaran kimia (logam berat) yang diatur di tiap negara Table 7. Kind of heavy metal contaminants regulated in different countries

\begin{tabular}{|c|c|c|c|c|c|c|}
\hline \multirow[b]{2}{*}{$\begin{array}{l}\text { Negara/ } \\
\text { Country }\end{array}$} & \multicolumn{5}{|c|}{ Logam berat/Heavy metal } & \multirow{2}{*}{$\begin{array}{c}\text { Metode } \\
\text { Pengujian/ } \\
\text { Testing method }\end{array}$} \\
\hline & $\begin{array}{l}\text { Arsen/ } \\
\text { Arsenic } \\
\text { (As) }\end{array}$ & $\begin{array}{l}\text { Kadmium/ } \\
\text { Cadmium } \\
\text { (Cd) }\end{array}$ & $\begin{array}{l}\text { Timbal/ } \\
\text { Lead } \\
(\mathrm{Pb})\end{array}$ & $\begin{array}{l}\text { Metilmerkuri/ } \\
\text { Methylmercury } \\
(\mathrm{MeHg})\end{array}$ & $\begin{array}{c}\text { Merkuri/ } \\
\text { Mercury } \\
(\mathrm{Hg})\end{array}$ & \\
\hline Indonesia/Indonesia & $\sqrt{ }$ & $\sqrt{ }$ & $\sqrt{ }$ & - & $\sqrt{ }$ & $\sqrt{ }$ \\
\hline Vietnam/Vietnam & - & $\sqrt{ }$ & $\sqrt{ }$ & $\sqrt{ }$ & $\sqrt{ }$ & - \\
\hline Thailand/Thailand & $\sqrt{ }$ & - & $\sqrt{ }$ & - & $\sqrt{ }$ & - \\
\hline Singapura/Singapore*) & $\sqrt{ }$ & $\sqrt{ }$ & $\sqrt{ }$ & - & $\sqrt{ }$ & - \\
\hline Malaysia/Malaysia**) & $\sqrt{ }$ & $\sqrt{ }$ & $\sqrt{ }$ & $\sqrt{ }$ & - & - \\
\hline China/China & $\sqrt{ }$ & $\sqrt{ }$ & $\sqrt{ }$ & $\sqrt{ }$ & - & - \\
\hline Jepang/Japan & - & - & - & $\sqrt{ }$ & $\sqrt{ }$ & - \\
\hline Korea Selatan/South Korea & - & $\sqrt{ }$ & $\sqrt{ }$ & $\sqrt{ }$ & $\sqrt{ }$ & - \\
\hline Amerika Serikat/United States of America & - & - & - & $\sqrt{ }$ & - & - \\
\hline Kanada/Canada & $\sqrt{ }$ & - & $\sqrt{ }$ & - & $\sqrt{ }$ & - \\
\hline $\begin{array}{l}\text { Austalia dan Selandia Baru/Australia dan } \\
\text { New Zealand }\end{array}$ & $\sqrt{ }$ & $\sqrt{ }$ & $\sqrt{ }$ & - & $\sqrt{ }$ & - \\
\hline Uni Eropa/European Union & - & $\sqrt{ }$ & $\sqrt{ }$ & - & $\sqrt{ }$ & $\sqrt{ }$ \\
\hline CAC/Codex Alimentariurs Commision & - & $\sqrt{ }$ & $\sqrt{ }$ & $\sqrt{ }$ & - & $\sqrt{ }$ \\
\hline
\end{tabular}

Keterangan/note:

*) Singapura juga mengatur batas maksimum cemaran tembaga/Singapore sets the maximum level of Copper (Cu)

${ }^{\star *}$ ) Malaysia juga mengatur batas maksimum cemaran antimon/Malaysia sets the maximum level of Antimony (Sb)

2015). Merkuri memiliki siklus biokimia yang kompleks, termasuk biomagnifikasi dan biotransformasi. Lebih dari 95\% metilmerkuri yang dicerna diserap oleh tubuh manusia. Merkuri organik seperti metilmerkuri merupakan bentuk yang paling berbahaya atau beracun dari merkuri yang menyebabkan efek neurotoksisitas yang dapat mempengaruhi perkembangan awal syaraf (Soares et al., 2018). Berdasarkan data penolakan, logam berat timbal $(\mathrm{Pb})$ tidak pernah menjadi penyebab adanya notifikasi penolakan produk perikanan Indonesia di negara tujuan ekspor.

Logam berat dapat menyebabkan risiko yang signifikan pada kesehatan manusia apabila tingkat paparan melebihi batas aman konsumsi yang diizinkan. Sebagai contoh, penelitian yang pernah dilakukan sebelumnya menyebutkan bahwa arsenik, kadmium, timbal, dan kromium memiliki efek yang berbahaya pada kesehatan manusia walaupun pada konsentrasi yang rendah. Kadmium berhubungan dengan efek pada hati, jantung, ginjal dan sistem reproduksi. Timbal dapat mempengaruhi sistem syaraf, mengganggu fungsi hematopoietic tulang, sistem reproduksi pada pria dan mengganggu sistem pencernaan (Zhong et al., 2018). Indonesia menetapkan batas maksimum cemaran merkuri pada ikan dan hasil olahannya, ikan predator, kekerangan dan udang. Batas maksimum cemaran merkuri di Indonesia terdapat pada SNI 7387:2009 tentang Batas Maksimum Cemaran Logam Berat dalam Pangan dan Peraturan Kepala BPOM Nomor 5 Tahun 2018 tentang Batas Maksimum Cemaran Logam Berat dalam Pangan Olahan. Terdapat perbedaan batas maksimum yang ditetapkan oleh 2 (dua) peraturan tersebut. BPOM menetapkan batas maksimum yang lebih rendah untuk arsen $(0,25 \mathrm{ppm})$ dan timbal $(0,2 \mathrm{ppm})$ dibandingkan dengan SNI yang menetapkan batas maksimum untuk arsen sebesar 1,00 ppm dan timbal sebesar 0,3 ppm. Batas maksimum timbal yang ditetapkan oleh BPOM juga lebih rendah dari pada batas maksimum yang ditetapkan oleh CAC yaitu sebesar 0,3 ppm. Batas maksimum logam berat tersebut juga dibedakan berdasarkan jenis produk perikanannya. Indonesia menetapkan batas maksimum kadmium untuk ikan, kekerangan, dan udang, sedangkan CAC hanya menetapkan batas maksimum untuk produk kekerangan. Berdasarkan penjelasan tersebut, dapat ditarik kesimpulan bahwa Indonesia lebih spesifik dibandingkan dengan CAC dalam penetapan produk perikanan.

Galimberti et al. (2016) dalam penelitiannya mendapatkan hasil bahwa konsentrasi cemaran kadmium berbeda pada 4 (empat) kategori produk perikanan, yaitu konsentrasi tertinggi hingga terendah 
terdapat pada moluska, krustasea, ikan predator dan ikan non predator. Konsentrasi merkuri tertinggi terdapat pada ikan predator, sedangkan ikan non predator dan krustasea memiliki konsentrasi merkuri yang hampir sama, sedangkan moluska memiliki konsentrasi merkuri yang paling rendah. Konsentrasi timbal tidak menunjukkan perbedaan yang signifikan pada keempat kategori produk tersebut. Penetapan batas maksimum cemaran logam berat yang ditetapkan oleh negaranegara lain tidak selalu sesuai dengan batas maksimum yang ditetapkan CAC, demikian pula dengan penentuan jenis produk perikanannya.

Produk yang paling banyak ditetapkan batas maksimumnya antara lain ikan dan hasil olahannya; ikan predator seperti cucut, tuna, marlin dan lain-lain (Tabel 8); kekerangan, moluska dan teripang; serta udang dan krustasea lainnya. Korea Selatan juga mengatur batas maksimum cemaran logam berat pada rumput laut. Thailand dan Singapura mengatur batas

Tabel 8. Batas maksimum cemaran logam berat pada ikan, ikan predator dan hasil olahannya Table 8. Maximum level for heavy metals in fish, predatory fish and their products

\begin{tabular}{|c|c|c|c|c|c|c|}
\hline \multirow[t]{2}{*}{ No } & \multirow[t]{2}{*}{ Negara/Country } & \multicolumn{5}{|c|}{$\begin{array}{c}\text { Batas Maksimum Logam Berat/ } \\
\text { Maximum level of heavy metal }(\mathrm{mg} / \mathrm{kg})\end{array}$} \\
\hline & & (As) & $(C d)$ & $(P b)$ & (MeHg) & $(H g)$ \\
\hline \multicolumn{7}{|c|}{ Ikan dan Hasil Olahannya/fish and fishery products } \\
\hline 1 & Indonesia (SNI)/Indonesia National Standar & 1 & 0.1 & $\left.0.3^{* *}\right)$ & - & $\left.0.50^{* *}\right)$ \\
\hline 2 & Perka BPOMRegulation of the Head of NADFC & 0.25 & 0.1 & 0.2 & - & 0.5 \\
\hline 3 & Codex Alimentariurs Commision (CAC) & - & - & 0.3 & 0.5 & - \\
\hline 4 & Uni Eropa/European Union & - & 0.05 & 0.3 & - & 0.5 \\
\hline 5 & Kanada/Canada & - & - & - & - & 0.5 \\
\hline 6 & China/China & 0.1 & 0.1 & 0.5 & 0.5 & - \\
\hline 7 & Korea Selatan/South Korea ${ }^{\text {d) }}$ & - & $0.10-0.20^{c)}$ & $0.5^{\mathrm{a})}$ & $1.0^{\mathrm{a})}$ & $0.50^{\mathrm{a})}$ \\
\hline 8 & Vietnam/Vietnam & - & 0.05 & $\left.0.3^{\star \star *}\right)$ & 0.5 & 0.5 \\
\hline 9 & Amerika Serikat/United States of America & - & - & - & 1 & - \\
\hline 10 & Jepang/Japan & - & - & - & 0.3 & 0.4 \\
\hline 11 & Malaysia/Malaysia & 1 & 1 & 2 & 0.5 & - \\
\hline 12 & Singapura/Singapore & - & $0.20^{f)}$ & - & - & 0.5 \\
\hline 13 & Thailand/Thailand & $\left.2.00^{*}\right)$ & - & $1.0^{f)}$ & - & $0.05^{f)}$ \\
\hline 14 & Australia dan Selandia Baru/Australia and New Zealand & $\left.2.00^{*}\right)$ & - & 0.5 & - & 1 \\
\hline \multicolumn{7}{|c|}{ Ikan predator misalnya cucut, tuna, marlin dan lain-lain/Predatory fish, ex. Shark, tuna, etc } \\
\hline 1 & Indonesia (SNI)/Indonesia National Standar & - & 0.5 & $0.4^{* *}$ & - & $\left.1.00^{* *}\right)$ \\
\hline 2 & Perka BPOMRegulation of the Head of NADFC & - & 0.3 & 0.4 & - & 1 \\
\hline 3 & Codex Alimentariurs Commision (CAC) & - & - & - & 1 & - \\
\hline 4 & Uni Eropa/European Union & - & $0.10-0.25^{\mathrm{e})}$ & - & - & 1 \\
\hline 5 & Kanada/Canada & - & - & - & - & 1 \\
\hline 6 & China/China & - & - & 1 & 1 & - \\
\hline 7 & Vietnam/Vietnam & - & $0.10-0.30^{b)}$ & - & 1 & 1 \\
\hline 8 & Malaysia/Malaysia & 1 & 1 & 2 & 1 & - \\
\hline 9 & Singapura/Singapore & - & $0.20^{f)}$ & - & - & 1 \\
\hline 10 & Thailand/Thailand & - & - & $1.0^{f)}$ & - & $0.05^{\dagger)}$ \\
\hline 11 & Australia dan Selandia Baru/Australia and New Zealand & - & - & - & - & 1 \\
\hline
\end{tabular}

\section{Keterangan/note:}

(-) Tidak tersedia/tidak ada/Not available

$\left.{ }^{*}\right)$ Anorganik arsen/Arsen anorganic

**) Juga mengatur standar terasi: $1,0 \mathrm{mg} / \mathrm{kg} /$ Standard regulation available for fish paste: $1.0 \mathrm{mg} / \mathrm{kg}$

$\left.{ }^{* * *}\right)$ Juga mengatur standar produk moluska (tanpa organ): $1,0 \mathrm{mg} / \mathrm{kg} /$ Standard regulation available for mollusk (without organ): $1.0 \mathrm{mg} / \mathrm{kg}$

a) Termasuk kepala ikan dan perut ikan/Include fish head and belly of fish

b) Tuna, makerel, sarden: $0,1 \mathrm{mg} / \mathrm{kg}$ dan todak: $0,3 \mathrm{mg} / \mathrm{kg} /$ Tuna, mackarel, sardine: $0.1 \mathrm{mg} / \mathrm{kg}$ and swordfish: $0.3 \mathrm{mg} / \mathrm{kg}$

c) Ikan air tawar dan ikan pelagis: $0.1 \mathrm{mg} / \mathrm{kg}$, dan ikan laut: $0.2 \mathrm{mg} / \mathrm{kg} /$ Freshwater fish and pelagic fish: $0.1 \mathrm{mg} / \mathrm{kg}$ and seafood: $0.2 \mathrm{mg} / \mathrm{kg}$

d) Alga: $0.3 \mathrm{mg} / \mathrm{kg} / \mathrm{algae}: 0.3 \mathrm{mg} / \mathrm{kg}$

e) Kisaran batas maksimum ditentukan pada masing-masing spesies sesuai CD 629/2008, 488/2014/The level for maximum limit is determined for each species refer to CD 629/2008, 488/2014

f) Produk pangan secara umum/For general food. 
maksimum logam berat untuk produk pangan secara umum, tidak dibedakan secara spesifik berdasarkan penggolongan ikannya.

Pada hasil kajian Sadhu et al. (2015), terdapat perbedaan batas maksimum metil merkuri pada ikan yang dikonsumsi yang ditetapkan pada Australian and New Zealand Food Standards Code (FSANZ) dan CAC. FSANZ menetapkan batas maksimum merkuri, sedangkan CAC menetapkan batas maksimum untuk metil merkuri. Batas maksimum merkuri untuk ikan yang berada pada tingkatan tropik rendah dan menengah yaitu 0,5 $\mu \mathrm{g} \mathrm{MeHg} / \mathrm{g}$, sedangkan batas maksimum metil merkuri untuk ikan predator yang berada pada tingkat tropik tertinggi ditetapkan lebih tinggi yaitu $1 \mu \mathrm{g} \mathrm{MeHg} / \mathrm{g}$. Adanya penolakan produk perikanan Indonesia yang disebabkan karena logam berat disebabkan karena kandungan logam berat pada produk perikanan tersebut melebihi batas maksimum yang telah ditentukan. Konsentrasi tertinggi terhadap merkuri pada produk perikanan Indonesia yang mengalami penolakan di Uni Eropa sebesar $3,13 \mathrm{mg} /$ $\mathrm{kg}$, maka dapat disimpulkan bahwa pengendalian atau monitoring terhadap cemaran logam berat pada produk perikanan di Indonesia belum dilaksanakan secara efektif.

Berdasarkan penelitian yang dilakukan oleh Samad, Berhimpon, Roike, dan Markus (2014), konsentrasi cemaran $\mathrm{Hg}$ yang terdapat pada ikan berbeda-beda tergantung dari ukuran dan berat ikan. Pada penelitian yang dilakukan pada unit pengolahan ikan di 2 (dua) lokasi yaitu Jakarta dan Bitung, konsentrasi Hg pada ikan oilfish (Ruvettus pretiosus) di Jakarta dan Bitung dengan berat $>30 \mathrm{~kg}$ berturutturut berkisar antara 1,76-2,26 ppm dan 1,76-2,19 ppm, sedangkan pada ikan dengan berat $11-29 \mathrm{~kg}$ memiliki kandungan $\mathrm{Hg}$ berturut-turut berkisar antara 0,85-0,96 ppm dan 0,65-0,89 ppm, dan pada ikan dengan berat $<10 \mathrm{~kg}$ memiliki kandungan $\mathrm{Hg}$ yang berkisar antara 0,21-0,87 ppm dan 0,19-0,87 ppm. Konsentrasi $\mathrm{Hg}$ pada ikan gindara (Lepidocybium flavobrunneum) di Jakarta dan Bitung dengan berat $>30 \mathrm{~kg}$ berturut-turut berkisar antara 1,49-1,93 ppm dan 1,37-1,71 ppm, sedangkan pada ikan dengan berat $11-29 \mathrm{~kg}$ memiliki kandungan $\mathrm{Hg}$ berturut-turut berkisar antara 0,63-1,31 ppm dan 0,76-1,61 ppm, dan pada ikan dengan berat $<10 \mathrm{~kg}$ memiliki kandungan $\mathrm{Hg}$ yang berkisar antara 0,01-0,37 ppm dan 0,03-0,39 ppm. Ikan oilfish dan ikan gindara termasuk dalam kelompok ikan predator.

Hasil penelitian Edward (2017) menunjukkan kandungan merkuri pada ikan dan kerang di Teluk Kao, Pulau Halmahera pada ikan gurara (Nemipterus japonicus) 0,98 ppm dan terendah terkandung pada ikan suo (Sphyraena jello) sebesar 0,15 ppm; sedangkan pada kerang darah (Anadara granosa) sebesar 0,42 ppm, dan pada kerang popaco (Telescopium telescopium) sebesar 0,05 ppm. Dari hasil penelitian tersebut diketahui kandungan merkuri pada ikan di Teluk Kao telah melebihi ambang batas yang ditetapkan oleh otoritas Indonesia dan CAC. Akumulasi $\mathrm{Hg}$ dalam biota laut ini tidak hanya terjadi di Teluk Kao, namun juga terjadi di beberapa tempat di Indonesia, misalnya, di perairan Bagan Siapiapi (Riau), Tanjung Balai (Sumut), Tanjung Jabung (Jambi), dan Muntok (Bangka), kadar merkuri dalam kerang darah (Anadara sp.) berkisar 0,05-2,02 ppb, di perairan Jawa (Tanjung Pasir, Dadap, Cilincing, Blanakan, Brebes, Demak, Sidoarjo, Pasuruan) 8,54-18,14 ppb, di perairan Banjarmasin, Balikpapan, Pontianak dan Makassar kadar merkuri dalam kerang Kepah (Anandontea alba) berkisar 0,29-2,16 ppb (Siregar \& Murtini, 2008). Di Gresik, ikan goang, glamo, putri ayu, sebelah, jenggot dan di Elat Tual, Maluku Tenggara, Lambis lambis, Anadara antiquate, Conus sp., Mactra maculate, Conus literatus memiliki kadar merkuri $<0,001$ ppm (Edward, 2012) dan di perairan Makassar kadar merkuri rerata dalam daging ikan kembung (Rastrelligersp.) dan kerang darah (Anadara sp.) masing-masing 1,35 ppm dan 0,77-3,11 ppm (Mangampe, Daud, \& Birawida, 2014).

\section{Standar Benzo[a]piren}

Pengasapan adalah salah satu contoh proses pengolahan ikan yang merupakan kombinasi dari proses pengeringan dan pemberian senyawa kimia alami pada produk misalnya fenol, aldehida, asam asetat dan berbagai jenis polycyclic aromatic hydrocarbon (PAH) (Essumang, Dodoo, \& Adjei, 2012). PAH termasuk dalam polutan lingkungan yang dihasilkan melalui pirolisis atau pembakaran senyawa organik yang tidak sempurna, misalnya pembakaran minyak bumi, kayu, sampah dan material organik lainnya (Chung et al., 2011). Kontaminasi lingkungan dan proses pengolahan pangan merupakan sumber utama keberadaan PAH pada pangan (Viegas, Novo, Pinho, \& Ferreira, 2012). PAH merupakan kelompok senyawa kimia kompleks yang terdiri dari 2 (dua) atau lebih cincin aromatik (Rose et al., 2015). PAH menjadi salah satu kelompok senyawa yang menyebabkan kanker, sehingga keberadaan PAH pada pangan menjadi salah satu kajian yang terus dilakukan. Salah satu senyawa $\mathrm{PAH}$ yang bersifat karsinogenik adalah benzo[a]piren (Wretling, Eriksson, Eskhult, \& Larsson, 2010).

Tidak semua negara menetapkan batas maksimum benzo[a]piren. Negara yang menetapkan batas maksimum antara lain Indonesia, China, Korea Selatan dan Uni Eropa (Tabel 9). CAC tidak menetapkan batas maksimum benzo[a]piren namun hanya menetapkan cara untuk mereduksi kontaminasi PAH pada pangan 
yang termuat dalam code of practice for the reduction of contamination of food with polycyclic aromatic hydrocarbons $(P A H)$ from smoking and direct drying processes (CAC/RCP 68-2009). Indonesia menetapkan batas maksimum untuk benzo[a]piren dan total benzo[a]piren, benz[a]anthracene, benzo[b]fluoranthane, dan chrysene yang tertuang pada SNI 7501:2009.

Penelitian Alomirah et al. (2011) memberikan hasil bahwa sebanyak 43 sampel $(60 \%)$ mengandung benzo[a]piren dengan konsentrasi di atas level yang terdeteksi (LOD), jumlah sampel yang mengandung benzo[a]piren ini lebih tinggi dibandingkan dengan penelitian dari European Food Safety Authority (EFSA) yaitu sebesar $41 \%$ terhadap sampel daging yang dipanggang dan diasap yang dilakukan oleh Uni Eropa. Farhadian, Jinap, Faridah, dan Zaidul, (2010) dalam penelitiannya menyebutkan bahwa konsentrasi tiga jenis PAH (fluoranthene, benzo[b]fluoranthene and benzo[a]piren) pada produk pangan yang di panggang menunjukkan hasil yang berbeda secara signifikan.

Produk ikan asap Indonesia mayoritas diekspor ke negara Jepang dan Korea Selatan. Berdasarkan data pada Tabel 4, diketahui bahwa produk ikan asap selama periode tahun 2007-2018 mendapat notifikasi penolakan oleh Korea Selatan sebesar 17,24\% yang disebabkan karena adanya kandungan benzo[a]piren yang melebihi batas. Produk ikan asap yang diekspor ke Korea Selatan tersebut, dipanggang menggunakan arang dengan suhu dipertahankan sebesar $70-80{ }^{\circ} \mathrm{C}$ dengan waktu pengasapan 24-48 jam, sehingga didapat produk katsuobushi. Hal tersebut sesuai dengan penelitian yang dilakukan oleh Chung et al. (2011) yang menyatakan bahwa kandungan PAH dalam daging sapi dan babi yang di panggang dengan menggunakan arang lebih tinggi dibandingkan dengan menggunakan oven, demikian pula dengan daging ayam yang dipanggang dengan menggunakan arang, maka kandungan $\mathrm{PAH}$ pada daging akan tinggi.

\section{Rekomendasi Penetapan Standar Cemaran Kimia pada Produk Perikanan di Indonesia}

Berdasarkan prinsip-prinsip pemenuhan kriteria pada CAC dan berdasarkan pengkajian standar cemaran kimia pada produk perikanan maka disusun beberapa rekomendasi perbaikan bagi penerapan standar cemaran kimia di Indonesia, baik peraturan cemaran yang disusun oleh Badan POM maupun BSN. Rujukan pada JECFA meetings merupakan acuan pemerintah dalam mengikuti perkembangan pembahasan standar kontaminan khususnya logam berat, sehingga penetapan batas maksimum cemaran memiliki dasar yang kuat selain dengan kajian paparan dan pola konsumsi nasional yang sudah ada. Penentuan jenis cemaran logam berat yang diatur dalam SNI maupun Peraturan Kepala BPOM dapat disesuaikan dengan jenis cemaran yang diatur dalam CAC yaitu dengan menambahkan cemaran

Tabel 9. Batas maksimum benzo[a]piren pada produk perikanan Table 9. Maximum level for benzo[a]pyrene in fishery products

\begin{tabular}{lcccc}
\hline & \multicolumn{4}{c}{ Benzo[a]pyrene } \\
\cline { 2 - 5 } Negara/Country & \multicolumn{2}{c}{ Benzo[a]piren (ppb) } & \multicolumn{2}{c}{$\begin{array}{c}\text { Total benzo[a]piren, } \\
\text { benz[a]anthracene, }\end{array}$} \\
\cline { 2 - 5 } & $\begin{array}{c}\text { Ikan olahan } \\
\text { yang diasap// } \\
\text { Smoked } \\
\text { fishery } \\
\text { product }\end{array}$ & $\begin{array}{c}\text { Kekerangan } \\
\text { yang diasap/ } \\
\text { Smoked } \\
\text { bivalve }\end{array}$ & $\begin{array}{c}\text { Ikan olahan diasap/ } \\
\text { ymoked } \\
\text { fishery } \\
\text { product }\end{array}$ & $\begin{array}{c}\text { Kekerang diasap/ } \\
\text { Smoked } \\
\text { bivalve }\end{array}$ \\
\hline Indonesia SNI/Indonesia National Standar & 5 & 10 & - & - \\
Indonesia BPOM/Indonesia NADFC & 5 & 6 & 12 & 35
\end{tabular}

Codex Alimentariurs Commision(CAC)

Uni Eropa/European Union ${ }^{* *}$
China/China

CAC tidak menetapkan batas maksimum, namun menetapkan code of practice terkait benzo[a]piren/CAC doesn't set up the maximum limit, however CAC published the code of practice to avoid benzo[a]pyrene

$\begin{array}{cc}2 & 6 \\ 5 & - \\ 5.0^{*} & 10\end{array}$

${ }^{\star}$ ) Termasuk moluska dan krustasea/Include mollusk and crustacea

${ }^{* *}$ ) Juga mengatur standar pada krustasea, cephalopoda: 5.0 ppb/Available for crustacea, cephalopoda: 5.0 ppb 
metilmerkuri, sehingga dapat dilakukan pengendalian yang lebih efektif mengingat penolakan di negara Korea Selatan disebabkan oleh metilmerkuri.

Berdasarkan data pada Gambar 1, bahwa penolakan ekspor produk perikanan Indonesia mayoritas disebabkan oleh logam berat meskipun di Indonesia telah menetapkan peraturan batas maksimum logam berat pada 2 (dua) peraturan yaitu SNI 7387:2009 dan Peraturan Kepala BPOM Nomor 5 Tahun 2018. Oleh karena itu perlu dilakukan pengetatan pengawasan terkait kandungan logam berat terhadap produk perikanan di Indonesia. Penolakan produk perikanan yang disebabkan karena kandungan benzo[a]piren yang masih terjadi, memerlukan adanya panduan produksi produk perikanan yang diolah dengan pengasapan, guna meminimalisir adanya kandungan benzo[a]piren yang melebihi ambang batas. Monitoring terkait cemaran logam berat juga sangat penting untuk dilakukan, sehingga diharapkan tidak terjadi penolakan dengan kasus serupa di negara tujuan ekspor sepanjang penerapan peraturan tersebut telah dilakukan dengan efektif, mengingat cemaran logam berat ini merupakan dampak dari adanya pencemaran pada lingkungan dan tidak dapat dihilangkan melalui proses pengolahan pangan yang ada. Secara lebih terperinci, rekomendasi yang diusulkan dapat dilihat pada Tabel 10.

Pengembangan suatu standar dilakukan melalui 2 (dua) pendekatan berbeda yaitu berbasis konsesus dan berbasis scientific evidence. Prinsip perumusan berdasarkan konsensus didasarkan pada kesepakatan terhadap suatu rancangan standar di kalangan para pemangku kepentingan, sedangkan yang berbasis scientific evidence didasarkan pada

Tabel 10. Rekomendasi terkait standar cemaran kimia pada produk perikanan di Indonesia Table 10. Recommendation for fishery contaminant standard in Indonesia

Aspek/Aspect

Format standar
kontaminan pada
pangan/Format
standard of
contaminants in foods

Penetapan standar
logam berat pada
produk
perikanan/Determinatio
$n$ of heavy metal
standard in fishery
products

Penerapan standar cemaran kimia pada produk perikanan/Implementati on of contaminants standard in fishery products
Rekomendasi/Recommendation

1. Penetapan tujuan standar cemaran kimia secara khusus/Determination of contaminants objectives specifically

2. Penetapan rujukan atau referensi berdasarkan JECFA meetings/Determination reference based on JECFA Meeting

1. Penetapan jenis logam berat yang diatur khususnya metilmerkuri sesuai dengan standar pada CAC/ Determination of methyl mercury contaminant which is regulated specifically in accordance with the standards of CAC

2. Pengkajian kembali metode pengujian merkuri pada SNI/Review of SNI testing method for mercury

1. Peningkatan program pengawasan atau monitoring cemaran kimia khususnya pada produk perikanan berdasarkan peraturan yang berlaku/ Improvement of monitoring programme for chemical contamination, especially on fishery products based on regulations
Tindak lanjut/Follow up

Revisi peraturan sesuai dengan format standar kontaminan/ Regulatory revisions according to the standard contaminant format

1. Melakukan analisis risiko terkait bahaya metilmerkuri pada produk perikanan di Indonesia/ Perform risk analysis related to methyl mercury in fishery products in Indonesia

2. Peningkatan kemampuan laboratorium pengujian/ Improvement of testing laboratory capabilities

1. Melakukan kajian kandungan logam berat pada produk perikanan berdasarkan area penangkapan/ Reviewing the heavy metal content of fishery products based on the fishing area

2. Penetapan cara pengolahan produk perikanan asap yang baik guna meminimalisir kandungan benzo[a]piren/ Determination of guidelines for processing of smoked fish in order to minimize the content of benzo[a]pyrene. 
kesepakatan terhadap suatu rancangan standar yang berlandaskan pada pembuktian secara ilmiah (BSN 2018). Berdasarkan CODEX STAN 193-1995, penetapan batas maksimum cemaran kimia ditetapkan berdasarkan perhitungan pada informasi toksikologi, data analisis, data asupan, dasar penggunaan teknologi, dan kajian risiko serta penetapan manajemen risiko. Informasi toksikologi cemaran memuat informasi tentang identifikasi bahan berbahaya/beracun, metabolisme cemaran pada manusia, dan informasi tentang tingkat keparahan dari cemaran. Data kualitatif dan kuantitatif terkait jumlah sampel, dan prosedur pengambilan sampel juga penting untuk diketahui. Informasi toksikologi cemaran dapat direpresentasikan melalui data Provisional Maximum Tolerable Daily Intake (PMTDI), Provisional Tolerable Weekly Intake (PTWI) atau Provisional Tolerable Monthly Intake (PTMI). Penetapan PMTDI/ PTWI/PTMI merupakan jumlah maksimum suatu zat dalam miligram per kilogram berat badan yang dapat dikonsumsi dalam sehari/seminggu/sebulan tanpa menimbulkan efek merugikan terhadap kesehatan.

CAC menerbitkan cara meminimalisir adanya kontaminasi cemaran kimia pada pangan melalui code of practice concerning source directed measures to reduce contamination of food with chemicals (CAC/ RCP 49-2001). Hal ini karena toksisitas setiap cemaran berbeda-beda. Otoritas negara-negara berserta organisasi internasional menginformasikan bahwa untuk meminimalisir potensi adanya kontaminasi pangan oleh cemaran kimia, dapat dilakukan dengan: mengendalikan emisi polusi industri, misalnya industri kimia, penambangan; mengendalikan pembuangan limbah rumah tangga ke perairan; dan melakukan pengendalian terhadap proses produksi.

\section{KESIMPULAN}

Penolakan ekspor produk perikanan Indonesia selama periode 2008-2017 mayoritas disebabkan oleh adanya cemaran logam berat, sehingga perlu dilakukan peningkatan monitoring kandungan logam berat pada produk perikanan yang dilakukan berdasarkan wilayah perairan di Indonesia. Peningkatan frekuensi monitoring pada saat penerimaan bahan baku di unit pengolahan ikan perlu dilakukan oleh eksportir guna meminimalisir adanya penolakan ekspor.

Indonesia menetapkan batas maksimum logam berat melalui 2 (dua) peraturan yaitu SNI 7387:2009 tentang Batas Maksimum Cemaran Logam Berat dalam Pangan dan Peraturan Kepala BPOM Nomor 5 Tahun 2018 tentang Batas Maksimum Cemaran Logam Berat dalam Pangan Olahan. Penetapan jenis cemaran kimia khususnya logam berat tidak sesuai dengan yang diatur dalam CAC. BPOM menetapkan batas maksimum yang lebih rendah dibandingkan dengan SNI yaitu untuk arsen dan timbal. Batas maksimum cemaran-cemaran tersebut lebih rendah dari pada batas maksimum yang ditetapkan oleh CAC. Harmonisasi metode pengujian merkuri pada SNI dengan standar Negara lain juga perlu dilakukan.

Indonesia telah menetapkan batas maksimum cemaran benzo[a]piren yang terdapat pada 2 (dua) peraturan yaitu SNI dan Peraturan Kepala BPOM, sementara itu CAC menetapkan code of practice terhadap benzo[a]piren. Penolakan produk perikanan karena adanya kandungan benzo[a]piren perlu dihindari dengan menetapkan pedoman cara produksi yang baik dengan menetapkan suhu dan waktu pengasapan yang tepat.

\section{DAFTAR PUSTAKA}

Agri-Food and Veterinary Authority. (2005). Sale of Food Act (Chapter 283, Section 56(1)), Food Regulation. Singapura.

Alomirah, H., Al-Zenki, S., Al-Hooti, S., Zaghloul, S., Sawaya, W., Ahmed, N., \& Kannan, K. (2011). Concentration and Dietary Exposure to Polycyclic Aromatic Hydrocarbons (PAHs) from Grilled and Smoked Foods. Food Control, 22, 2028-2035

Anual, Z. F., Maher, W., Krikowa, F., Hakim, L., Ahmad, N. I., \& Foster, S. (2018). Mercury and risk assessment from consumption of crustacean, cephalopods and fish from West Peninsular Malaysia. Microchemical Journal, 140, 214-221.

Badan Pengawas Obat dan Makanan RI. (2009). Peraturan Kepala Badan Pengawas Obat dan Makanan Republik Indonesia Nomor HK.00.06.1.52.4011 tentang Penetapan Batas Maksimum Cemaran Mikroba dan Kimia Dalam Makanan. Jakarta: Badan POM RI.

Badan Pengawas Obat dan Makanan RI. (2018). Peraturan Kepala Badan Pengawas Obat dan Makanan Republik Indonesia Nomor 5 tahun 2018 tentang Batas Maksimum Cemaran Logam Berat Dalam Pangan Olahan. Jakarta: Badan POM RI.

Badan Pengawas Obat dan Makanan RI. (2018). Peraturan Kepala Badan Pengawas Obat dan Makanan Republik Indonesia Nomor 8 tahun 2018 tentang Batas Maksimum Cemaran Kimia Dalam Pangan Olahan. Jakarta: Badan POM RI.

Badan Standardisasi Nasional RI. (2009). SNI 7387:2009 tentang Batas Maksimum Cemaran Logam Berat dalam Pangan. Jakarta: BSN RI.

Badan Standardisasi Nasional RI. (2009). SNI 7501:2009 tentang Batas maksimum cemaran kimia (benzo[a]piren, dioksin $(2,3,7,8-T C D D)$, 1,3dikloropropan-2-ol (1,3-DCP), dan 3monokloropropan-1,2-diol (3-MCPD)) dalam pangan. Jakarta: BSN RI. 
Badan Standardisasi Nasional RI. (2011). SNI 2354.5:2011 tentang Penentuan Kadar Logam Berat Timbal ( $P b)$ dan Kadmium (Cd) pada Produk Perikanan. Jakarta: BSN RI.

Badan Standardisasi Nasional RI. (2016). SNI 2354.6:2016 tentang Penentuan Kadar Logam Berat Merkuri $(\mathrm{Hg})$ pada Produk Perikanan. Jakarta: BSN RI.

Badan Standardisasi Nasional. (2018). Perumusan SNI. diakses dari http://www.bsn.go.id/main/bsn/isi_bsn/ 20169/perumusan-sni.

Badan Standardisasi Nasional. (2018). Tentang SNI. diakses dari http://www.bsn.go.id/main/sni/isi_sni/5.

Bentley, K., \& Soebandrio, A. (2017). Arsenic and Mercury Concentrations in Marine Fish Sourced from Local Fishermen and Fish Markets in Mine-Impacted Communities in Ratatotok Sub-district, North Sulawesi, Indonesia. Marine Pollution Bulletin, 120, 75-81.

Codex Alimentarius Commission. (1995). General Standard For Contaminants and Toxin in Food and Feed, CODEX STAN 193-1995. Rome, CAC.

Codex Alimentarius Commission. (2001). Code of Practice Concerning Source Directed Measures to Reduce Contamination of Food with Chemicals. CAC/ RCP 49-2001. Rome, CAC.

Chung, S. Y., Ramesh, R. Y., J. S. Kim, K. Kwon, M. C. Kim, \& David B. M. (2011). Effects of grilling and roasting on the levels of polycyclic aromatic hydrocarbons in beef and pork. Food Chemistry, 129, 1420-1426.

Edward. (2012). Akumulasi logam berat dalam beberapa jenis ikan komersil di Gresik. Jawa Timur. Prosiding: Seminar Nasional Perikanan Indonesia, 13-14 November 2012, STP Jakarta, 104-114.

Edward. (2017). Kajian awal kadar merkuri $(\mathrm{Hg})$ dalam ikan dan kerang di Teluk Kao, Pulau Halmahera. Jurnal IImu-ilmu Perairan, Pesisir dan Perikanan, 6 (3), 188-198.

Essumang, D. K., Dodoo, D. K., \& Adjei, J. K. (2012). Polycyclic Aromatic Hydrocarbon (PAH) contamination in smoke-cured fish products. J. of Food Composition and Analysis, 27, 128-138.

European Commission. (2002). Opinion of the Scientific Committee on Food on the Risk to Human Health of Polycyclic Aromatic Hydrocarbons in Food. Institute for Reference Materials and Measurements. Geel.

European Commission. (2006). Commision Regulation (EC) No. 1881/2006 of 19 December 2006 on Setting maximum levels for certain contaminants in foodstuffs. Brussels: EU Commission.

European Commission. (2008). Commision Regulation (EC) No. $629 / 2008$ of 2 July 2008 amending Regulation (EC) No. 1881/2006 on Setting maximum levels for certain contaminants in foodstuffs. Brussels: EU Commission.

European Commission. (2011). Commision Regulation (EC) No. 420/2011 of 29 April 2011 amending Regulation (EC) No. 1881/2006 on Setting maximum levels for certain contaminants in foodstuffs. Brussels: EU Commission.

European Commission. (2012). Official Methods for the Determination of Heavy Metals in Feed and Food. SCF/CS/CNTM/PAH/29/Final.

European Commission. (2014). Commision Regulation (EC) No. 488/2014 of 12 May 2014 amending Regulation (EC) No. 1881/2006 as regard maximum levels of Cadmium in foodstuffs. Brussels: EU Commission.

European Commission. (2014). Commision Regulation (EC) No. 1327/2014 of 12 December 2014 amending Regulation (EC) No. 1881/2006 as regard maximum levels of polycyclic aromatic hydrocarbons (PAHs) in traditionally smoked meat and meat products and traditionally smoked fish and fishery products. Brussels: EU Commission.

European Commission. (2015). Commision Regulation (EC) No. 2015/1005 of 25 June 2015 amending Regulation (EC) No. 1881/2006 as regard maximum levels of Lead in Certain foodstuffs. Brussels: EU Commission.

European Commission. (2015). Commision Regulation (EC) No. $2015 / 1125$ of 10 July 2015 amending Regulation (EC) No. 1881/2006 as regard maximum levels for polycyclic aromatic hydrocarbons in Katsuobushi (dried bonito) and certain smoked Baltic herring. Brussels: EU Commission.

European Union. (2018). The Rapid Alert System for Food and Feed (RASFF) Annual Report: 2017. Publications Office of the European Union. Luxembourg.

Farhadian, A., Jinap, S., Abas, F., \& Sakar, Z. I. (2010). Determination of Polycyclic Aromatic Hydrocarbons in Grilled Meat. Food Control, 21, 606-610.

Food and Drug Administration. (2010). Action level for Poisonous or deleterious substances in human food and animal feed. Retrieved from https://www.fda.gov/ regulatory-information/search-fda-guidancedocuments/guidance-industry-action-levelspoisonous-or-deleterious-substances-human-foodand-animal-feed.

Food Standards Australia and New Zealand. (2017). Food standard Australia New Zealand Act (Schedule 19. Maximum level of contaminants and natural toxicants). Australia.

Galimberti, C., Ivan, C., Massimo, C., Vittorio, M. M., Simonetta, M., Umberto, G., \& Donatella, C. (2016). Evaluation of mercury, cadmium and lead levels in fish and fishery products imported by air in North Italy from extra-European Union Countries. Food Control, 60, 329-327.

Health and Food Safety, European Union. (2018). Rapid Alert System for Food and Feed Annual Report 2017. Publications Office of the European Union: Luxembourg. Retrieved from https://ec.europa.eu/ food/sites/food/files/safety/docs/ rasff_annual_report_2017.pdf

Health Canada. (2008). Human Health Risk Assessment of Mercury in Fish and Health Benefits of Fish 
Consumption. Retrieved from http://www.canada.ca/ en/health-canada/services/food-nutrition/reportspublications/human-helath-risk-assessmentmercury-fish-health-benefits-fish-consumption.html.

Health Canada. (2018). List of contaminants and other adulterating substances in foods. Retrieved from https://www.canada.ca/en/health-canada/services/ food-nutrition/food-safety/chemical-contaminants/ contaminants-adulterating-substances-foods.html.

Japan External Trade Organization. (2011). Specifications and standards for food, food additive, etc Under the Food Sanitation Act (Abstract) 2010. Tokyo.

Kementerian Kelautan dan Perikanan. (2018). Data Time Series Volume Produksi Perikanan Nasional Periode 2014 hingga 2017. Jakarta (ID): Kementerian Kelautan dan Perikanan RI.

Margampe, A., Daud, A., \& Birawida, A. B. (2014). Analisis risiko merkuri $(\mathrm{Hg})$ dalam ikan kembung dan kerang darah pada masyarakat di wilayah pesisir Kota Makassar. Makalah: Bagian Kesehatan Lingkungan Fakultas Kesehatan Masyarakat Universitas Hasanuddin: 15 hal. Diakses pada 28 Oktober 2018.

Ministry of Food and Drug Safety. (2017). Food Code. Seoul.

Ministry of Health. (1985). Food Regulation 1985. Malaysia.

Ministry of Health. (2011). National technical regulation on the limits of heavy metals contamination in food, QCVN 8-2:2011/BYT. Hanoi.

Ministry of Health. (2011). National technical regulation on maximum level of mycotoxin allowed in food, QCVN 8-1:2011/BYT. Hanoi.

Ministry of Public Health. (1986). Notification of the Ministry of Public Health No. 98 (B.E.2529): Prescribing Standards of Contaminated Substances. Thailand.

Ministry of Public Health. (2003). Notification of the Ministry of Public Health No. 273 (B.E.2546): Standards of Contaminants in Food (No.2). Thailand.

Ministry of Science, Technology and Innovation. (2012). Standards of Malaysia Act 1996 (Act 549). Malaysia.

Nunez, R., Garcia, M. A., Julian, A., \& Melgar, M. J. (2018). Arsenic, cadmium and lead in fresh and processed tuna marketed in Galicia (NW Spain): risk assesment of dietary exposure. Science of the Total Environment, $627,322-331$.

Peraturan Pemerintah RI Nomor 102 tahun 2000 tentang Standardisasi Nasional.

Peraturan Pemerintah RI Nomor 28 tahun 2004 tentang Keamanan Mutu dan Gizi Pangan.

Rapid Alert System for Food and Feed Portal. (2018). Diakses dari https://webgate.ec.europa.eu/rasffwindow/portal/?event=searchForm\&cleanSearch $=1$.

Rose, M., Joe, H., Alan, D., Steve, (RG) P., Shaun, W., Alwyn, F., \& David, M. (2015). Investigation Into the Formation of PAHs in Food Prepared in the Home to Determine the Effects of Frying, Grilling, Barbecuing, Toasting and Roasting. Food and Chemical Toxicology. 78, 1-9.

Sadhu, A. K., Jonathan, P. K., Hamish, F., \& Ben B. (2015). Methyl Mercury Concentrations in Edible Fish and
Shellfish from Dunedin, and Other Regions around the South Island, New Zealand. Marine Pollution Bulletin.htt p://dx.doi.org/10.1016/ j.marpolbul.2015.10.013

Samad, S., Berhimpon, S., Roike, I. M., \& Markus, T. L. (2014). Kandungan merkuri $(\mathrm{Hg})$ pada oilfish (Ruvettus pretiosus) dan escolar (Lepidocybium flavobrunneum) pada unit pengolahan ikan di Jakarta dan Bitung, Indonesia. Aquatic Science \& Management. Edisi Khusus 2: 49-52.

Shao, Y., Wang, J., Chen, X., \& Wu, Y. (2014). The consolidation of food contaminants standards in China. Food Control, 43, 213-216.

Siregar, H. T., \& Murtini, J. T. (2008). Kandungan logam berat pada beberapa lokasi perairan Indonesia pada tahun 2001 sampai dengan tahun 2005. Squalen. 3(1): 7-15.

Soares, J. M., Jose, M. G., Marcelo, R. A., Josianne, N. S., Flavia, B. C., \& Beatriz, M. A. G. (2018). Mercury in fish from the madeira river and health risk to Amazonian and Riverine populations. Food Research International.DOI: 10.1016/j.foodres.2018.04.069.

Stojanovic, J. D., Dragica, N., Danijela, V., Srdjan, S., Milan, M., Jelena, B., \& Sasa, J. (2015). Distribution of mercury in three marine fish species. Procedia Food Science, 5, 65-68.

Suryana. (2010). Metode penelitian: model praktis penelitian kuantitatif dan kualitatif. Bandung: Universitas Pendidikan Indonesia.

The National Helath and Family Planning of People's Republic of China. (2012). National food safety standard of maximum levels of contaminants in foods (GB 2762-2012). Beijing.

United Nations Industrial Development Organization. (2018). Diakses dari https://www.unido.org/ resources/publications/advancing-economiccompetitiveness/quality-and-complianceinfrastructure/trade-standards-compliance-report/ trade-standards-compliance-footprints.

Viegas, O., Novo, P., Pinho, O., \& Ferreira, I. M. P. L. V. O.. (2012). A Comparison of the Extraction Procedures and Quatification Methods for the Chromatographic Determination of Polycyclic Aromatic Hydrocarbons in Charcoal Grilled Meat and Fish. Talanta, 88, 677683.

Wretling, S., Eriksson, A., Eskhult, G. A., \& Larsson, B. (2010). Polycyclic aromatic hydrocarbons (PAHs) in Swedish smoked meat and fish. Journal of Food Composition and Analysis, 23(3), 264-272. https:// doi.org/10.1016/j.jfca.2009.10.003

Zaza, S., de Balogh, K., Palmery, M., Pastorelli, A. A., \& Stacchini, P. (2015). Human exposure in Italy to lead, cadmium and mercury through fish and seafood product consumption from Eastern Central Atlantic Fishing Area. Journal of Food Composition and Analysis, 40, 148-153. https://doi.org/10.1016/ j.jfca.2015.01.007

Zhong, W., Yanfeng, Z., Zihao, W., Rongyan, Y., Xinyue, C., Jing, Y., Lingyan, Z. (2018). Health risk assessment of heavy metals in freshwater fish in the Central and Eastern North China. Ecotoxicology and Environmental Safety, 157: 343-349. 